\title{
How to Translate a Bioassay Into a Screening Assay for Natural Products: General Considerations and Implementation of Antimicrobial Screens
}

Authors

Affiliation
Adyary Fallarero, Leena Hanski, Pia Vuorela

Division of Pharmaceutical Biosciences, Centre for Drug Research, Faculty of Pharmacy, University of Helsinki, Helsinki, Finland

\author{
Key words \\ - assay validation \\ - screening \\ - antibacterial drug discovery \\ - ChemGPS-NP \\ - natural products \\ - impedance
}

\section{Abstract \\ $\nabla$}

Natural product sources have been a valuable provider of molecular diversity in many drug discovery programs and several therapeutically important drugs have been isolated from these. However, the screening of such materials can be very complicated due to the fact that they contain a complex mixture of secondary metabolites, but also the purified natural compounds exert a challenge for bioactivity screening. Success in identifying new therapeutics using in vitro bioassays is largely dependent upon the proper design, validation, and implementation of the screening assay. In this review, we discuss some aspects which are of significant concern when screening natural products in a microtiter plate-based format, being partly applicable to other assay formats as well, such as validation parameters, layouts for assay protocols, and common interferences caused by natural products samples, as well as various troubleshooting strategies. Examples from the field of natural product drug discovery of antibacterial compounds are discussed, and contributions from the realm of academic screenings are highlighted.

Bibliography

DOI http://dx.doi.org/

10.1055/s-0034-1383061

Published online September 15, 2014

Planta Med 2014; 80 :

1182-1199 @ Georg Thieme

Verlag KG Stuttgart · New York . ISSN 0032-0943

\section{Correspondence}

Adyary Fallarero

Division of Pharmaceutical Biosciences

Centre for Drug Research

Faculty of Pharmacy

University of Helsinki

Viikinkaari 5E

Viikki Biocenter, 00014

Finland

Phone: + 358442834933

adyary.fallarero@helsinki.fi

\begin{tabular}{|c|c|}
\hline \multicolumn{2}{|c|}{ Abbreviations } \\
\hline ARS: & aminoacyl-t-RNA synthetase \\
\hline CV: & coefficient of variation \\
\hline DLS: & dynamic light scattering \\
\hline ECIS: & $\begin{array}{l}\text { electric cell-substrate impedance } \\
\text { sensing }\end{array}$ \\
\hline EthD-1: & ethidium homodimer-1 \\
\hline Fab: & fatty acid biosynthesis \\
\hline FP: & fluorescence polarization \\
\hline FRET: & $\begin{array}{l}\text { fluorescence resonance energy } \\
\text { transfer }\end{array}$ \\
\hline GFP: & green fluorescent protein \\
\hline HCS: & high-content screening \\
\hline HTS: & high-throughput screening \\
\hline LUO: & laboratory unit operation \\
\hline MTS: & medium-throughput screening \\
\hline MTT: & $\begin{array}{l}\text { 3-(4,5-dimethylthiazol-2-yl)-2,5-di- } \\
\text { phenyltetrazolium bromide }\end{array}$ \\
\hline NP: & natural products \\
\hline PC: & photonic crystal \\
\hline S/B: & signal-to-background ratio \\
\hline S/N: & signal-to-noise ratio \\
\hline SPR: & surface plasmon resonance \\
\hline SW: & signal window \\
\hline T3SS: & type 3 secretion system \\
\hline TEM: & transmission electron microscopy \\
\hline $\begin{array}{l}\text { uHTS: } \\
\text { Z': }\end{array}$ & $\begin{array}{l}\text { ultrahigh-throughput screening } \\
\text { screening window coefficient }\end{array}$ \\
\hline
\end{tabular}

tive and the use has varied among authors. HTS generally implies that between 10000 and 100000 compounds (or samples) per day are screened, while MTS refers to campaigns involving around 1000 to 10000 compounds per day [1]. Screening a lower amount of a sample is then regarded as "low-throughput screening", while the other extreme, uHTS, implies that more than 100000 data points are generated per day $[1,2]$. Regardless of the throughput, three basic and interconnected elements have been reasonably ar- 
gued as critical for the success of screening campaigns: 1) targets, 2) screening methods, and 3) chemical libraries.

The selection of a single target has typically been driven by the disease relevance and the chemical tractability. While the onetarget approach has allowed for the exploration of very large compound collections in a fast and cost-effective manner, it has also been a reductionist by ignoring the biochemical networks inherently existing in biological systems. Because of that, recent views have shifted the target selection process towards finding a set of multiple targets associated with the desired clinical effects [3]. That relates to the second aspect - the selection of screening methods. The more general choice has been between biochemical and cell-based assays. With the resurgence of polypharmacology and multiple-target approaches, cell-based methods, in particular phenotypic and pathway assays, have become more prevalent when performing screenings. For the first screens, also known as "primary" screens, using either biochemical or cell-based assays, compounds are tested only once and the follow-up strategies are decided based upon these results. This implies that the assay has to be shown to perform robustly. In general, any level of automation of in vitro assays increases throughput, decreases human errors and need for labor, and improves safety issues. The third critical element is the selection of compounds to be screened. Very large synthetic chemical collections of millions of compounds have now been made available, but the positive impact of using natural compound collections is undeniable, especially in certain therapeutic areas.

Natural compounds have provided milestone drugs, i.e., taxol, statins, and cyclosporine, with very successful roles in modern pharmacotherapy. For instance, antibacterial drugs of natural origin (natural compounds or their semisynthetic modifications) account for more than $65 \%$ of all antibacterial drugs approved over the last 30 years [4]. Another example is provided by anticancer drugs, in which a staggering $50 \%$ of all existing medications are natural products or molecules derived therefrom [5]. Besides their roles as lead compounds, natural products provide starting scaffolds for structural optimization via combinatorial chemistry or serve as chemical tools for the validation of new molecular targets [6]. They are also a more successful choice when screening against protein-protein targets, because they tend to be larger and, in many cases, more complex than synthetic libraries [7].

When aimed specifically at the exploration of natural products and the development of screening assays that encounter specific challenges. The screening of natural origin samples can involve crude extracts (10-1000 or more compounds), semi-purified mixtures (5-10 compounds), or structure-elucidated purified single compounds. This structural complexity of the extracts has historically been the most daunting factor influencing the work with natural products. From the assay perspective, one challenge is that screening methods are run under experimental conditions that jeopardize the proper identification of actives within the complex natural mixtures, thus rendering more false negatives, as some active components can be present at very low concentrations [8]. Another problem is that several natural compounds are known to aggregate in biochemical buffers, causing nonspecific inhibition of unrelated enzymes. For instance, unexpected behavior of natural retinoids in a filter-binding assay to bovine and reindeer $\beta$-lactoglobulin was shown to be explained by detecting aggregate formation [9]. They can also cause interferences with optical detection methods, as they can display intrinsic fluorescence or cause light scattering, among other things.
Therefore, in this review, several such methodological challenges will be discussed and concrete approaches will be recommended to circumvent them. To exemplify how these methodological challenges can be encountered in a relevant area for natural product researchers, we selected the discovery of antibacterial drugs. This review does not pretend to be comprehensive, but it does aim to serve as a first-hand tool for natural product researchers to recognize problems during screening campaigns and adopt specific resolution strategies.

\section{Development and Validation of Screening Assays} $\nabla$

The general workflow

The development and implementation of appropriated assays are indispensable steps prior to the performance of chemical screens. These steps are performed within the early drug discovery phase commonly refereed as "Target-to-Lead". The general workflow of the "Target-to-Lead" phase is schematically represented in - Fig. 1, while specific issues that need to be considered during the discovery of natural origin drugs are summarized in $\odot$ Table 1. Most of the issues that will be discussed in this review are applicable across all variants of performed screens (from high to low throughput). However, an intentional emphasis has been put into considerations that are applicable to MTS as this corresponds with the most frequent type of screens currently performed in academic environments worldwide. Indeed, with the growing engagement of academic centers in the performance of MTS (and, in many cases, also of HTS), the term "drug screening" has also become less used and the more general "chemical screening" has been adopted instead, as this is not biased towards a therapeutic goal and it better reflects the wider interests of the academic community [10].

The "Target-to-Lead" phase ( $\bullet$ Fig. 1 ) starts with the selection of a target, which is greatly influenced by the relevance to the disease in question and the chemical tractability. At this stage, striking a balance between the novelty and the validity of the chosen target is an important goal since this will ultimately determine the type of drug that may be discovered - a new type of drug or a drug similar to an existing one. Target novelty and validity generally have an inverse relationship. Validated targets with known disease relevance generally lack novelty, while on the other hand novel targets typically require further validation studies (i.e., cellbased and animal trials) to ensure that screens provide meaningful results and lead to the discovery of clinically valuable compounds [7]. Using drug discovery strategies with both types of targets have pros and cons, and concrete examples of them will be given in section 4 of this review when discussing the discovery of natural antibacterial compounds.

Upon selecting a target, an assay method needs to be chosen so that the activity of the test compounds against the target is measured either in the absence or presence of cells. The development process ideally aims at providing an assay that combines simplicity with good sensitivity, reproducibility, and accuracy, as well as amenability to automation and reasonable price [11,12]. In terms of simplicity, the goal is to develop assays that do not have many steps (not more than 5-10) and only necessitate simple operations, with a preference towards assays that only involve additions, otherwise known as homogeneous. The sensitivity of the assay must be sufficient to permit the identification of low potency or low efficacy compounds. The accuracy refers to the ability of the assay to provide trustable results as assessed via control 


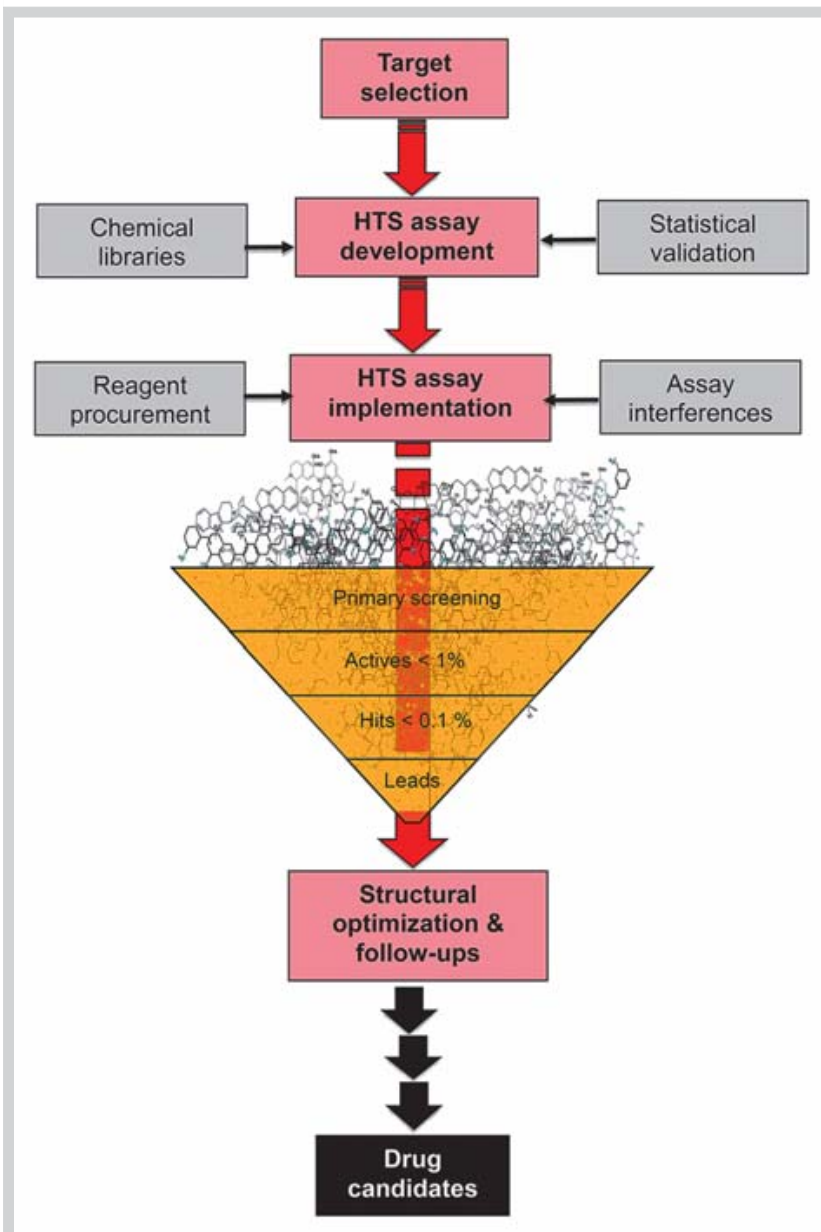

Fig. 1 Workflow describing the general steps of the HTS process (red boxes) within the overall process of discovering new drug candidates. (Color figure available online only.) compounds with known pharmacological effects on the measured targets, while the reproducibility of the assay relates to the stability of the response that is offered by the assay, to ensure that similarly trustable results are obtained when the assay is performed in different wells, plates, days, and by different human operators or using different types of laboratory equipment [13]. The reproducibility of the assay is also tightly connected to the assay reagents, both chemical and biological. These need to be stable and no significant changes in assay components should be detected, especially in cases of non-commercially available reagents that may be prepared in-house in different batches, such as recombinant proteins or cell suspensions.

Assuming that the target is chemically tractable, it is fairly safe to say that most assays can be engineered and conditions can be optimized so that compounds modulating the target are found in the tested collections. Examples of the conditions needed to be optimized for both biochemical and cell-based assays are presented in O Fig. 2. To follow the optimization process and test the effects that these different conditions have on the quality of the assay, statistical analysis are performed, which will be discussed in the next chapter.

When it comes to academic screening centers or groups, they have been particularly successful in the development and adoption of a cell-based, phenotypic screening (recently reviewed by [10]) as a strategy to cover diseases that have been neglected by pharmaceutical companies and access a wider spectrum of targets [14]. The development of high-quality cell-based assays combined with the selection of well-designed academic libraries (not necessarily larger ones) has translated into the discovery of highly active molecules that maintain a very high activity in vivo as well (i.e., [15]).

Academic institutions have also contributed with innovative studies incorporating HCS, not only during the primary screening phase but also for the determination of the mode of actions of actives (i.e., [16]). The complex data processing, which was the major drawback for the use of HCS, is now being overcome by the

Table 1 Key aspects of the HTS assay optimization, validation, and implementation process specific to the early drug discovery of natural products.

\begin{tabular}{|c|c|c|c|}
\hline & General considerations & Some key issues NP & Discussed here \\
\hline \multirow[t]{5}{*}{ HTS assay development } & Assay configuration & $\begin{array}{l}\text { Some technologies can be more likely to fail when applied } \\
\text { to NP. } \\
\text { Some plate materials can cause increased adsorption of } \\
\text { NP mixtures. }\end{array}$ & - \\
\hline & Assay conditions & $\begin{array}{l}\text { Low concentrations of NPs in complex mixtures can } \\
\text { challenge detection limits of the assays. } \\
\text { Compatibility of specific solvents used for natural products } \\
\text { need to be tested. }\end{array}$ & - \\
\hline & Automation & $\begin{array}{l}\text { Pipetting protocols and automated handling of natural } \\
\text { products need to be finely tuned. }\end{array}$ & Section 3.1 \\
\hline & Miniaturization & $\begin{array}{l}\text { Amounts of NP or extracts availability can be very limited, } \\
\text { driving the need for miniaturization. }\end{array}$ & Section 3.1 \\
\hline & HTS statistical quality & $\begin{array}{l}\text { Control of statistical quality is imperative in HTS but lacking } \\
\text { in many NP screening studies. }\end{array}$ & Section 2.2 \\
\hline HTS assay implementation & $\begin{array}{l}\text { Identification and elimination } \\
\text { of interferences }\end{array}$ & $\begin{array}{l}\text { Common interferences due to colloidal aggregation of } \\
\text { natural compounds need to be addressed. } \\
\text { Methods need to be chosen to exclude optically interfering } \\
\text { natural compounds. } \\
\text { - Chemically reactive NPs can cause false positives or } \\
\text { negatives. }\end{array}$ & Section 3.2 \\
\hline Lead refinement & Selection in hit-to-lead process & $\begin{array}{l}\text { Structural complexity can hamper chemical synthesis or } \\
\text { the structural optimization process. }\end{array}$ & - \\
\hline
\end{tabular}




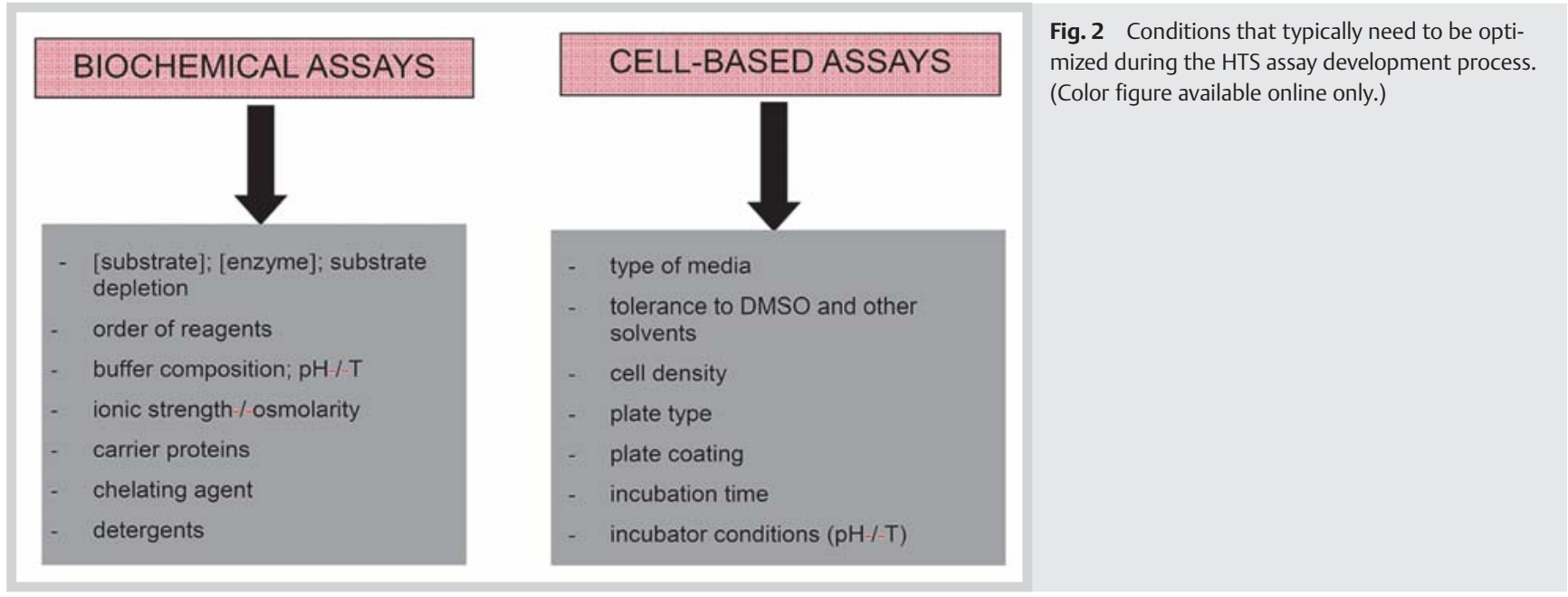

scientific community with the project Open Microscopy Environment that has provided entirely open solutions, such as OMERO [17]. OMERO allows for the open analysis of complex multidimensional image data as well as the storage and handling of scientific image repositories. Such tools have allowed HCS data to be exchanged between multiple platforms and be free of dependency from closed and often expensive commercial solutions [10]. Furthermore, another interesting feature of academic screening has been the implementation of whole organism screens employing nematodes or zebra fish, which in some cases have been applied in conjunction with HCS [18]. More examples of this type of screen will be further discussed in section 4 .

\section{Statistical analysis}

Assay performance and assay sensitivity have been suggested by authorities in the field as the two crucial aspects that should be monitored during the development of screening assays [11,19]. In general, an assay is thought to perform well if it provides an adequate distinction between maximum and minimum signals, which, in other words, indicates that the assay can effectively differentiate between the non-actives that largely populate chemical collections and the less frequently existing actives. Also, a good reproducibility needs to be demonstrated. For this purpose, certain statistical parameters characterizing the assay performance are calculated. In large pharmaceutical organizations, they are an essential part of the routine operations performed in HTS laboratories, and a considerable amount of literature has been dedicated to them. However, in academic groups, especially in those dedicated to the MTS of natural products, they are less known and their application is consequently much less reported. In Table 2, a summary of the relevant parameters needed to assess the performance of screening assays is presented.

Since first being published in 1999 by Zhang et al. [20], Z' has become one (if not the most) useful tool to estimate assay performance. Based upon the assumption that the signals are binomially distributed ( $99 \%$ of their data points fall within the $\pm 3^{*}$ standard deviation limits), $Z^{\prime}$ estimates if a statistically significant separation between the extreme assay responses (maximum and minimum) exists in the assay. When the $Z^{\prime}$ value is over 0.5 (or 0.4 in the case of cell-based assays), the assay can be considered a good performing screening method. Conversely, $Z^{\prime}$ is close or equals to 0 when the extreme signals of the assays overlap, which is an indication of a poor quality assay. As seen in 0 Table 2 , the calcula- tion is very simple, and it is independent of the assay format or the technology being used. In fact, $Z^{\prime}$ is a dimensionless parameter that can be used to compare between runs performed in different conditions. For calculating $Z^{\prime}$, we first recommend performing normality tests on the control samples with any reliable statistical software package to ensure that the prerequisite of a binomial distribution is fulfilled. Then, a second step would focus on preparing and running assay control plates under different assay conditions ( $\odot$ Fig. 2 ), that is, plates containing only control samples (maximum and minimum signals), to identify and establish the assay performance and variability across different wells, plates, and days. At this stage, reagent stability should also be studied to exclude other possible sources of errors during the assay implementation.

The same data generated during this initial optimization run permits the calculation of S/B and S/N ratios. S/B as a stand-alone parameter has a limited value since it does not take into account the signals variability. On the other hand, the $\mathrm{S} / \mathrm{N}$ ratio, when calculated based on the modified equation published by Bollini et al. [21], does provide a good assessment of both signal window and signal variability. In any case, both parameters are nowadays typically used in conjunction with $Z^{\prime}$.

The $Z^{\prime}$ equation can also be rewritten to make the relationship with the $\mathrm{S} / \mathrm{B}$ ratio and the signal variations expressed as CVs more evident, as correctly indicated by [7]:

$\mathrm{Z}^{\prime}=1-0.03 * \frac{\left(\left|\frac{\mathrm{S}}{\mathrm{B}}\right| * \mathrm{CV} \max +\mathrm{CVmin}\right)}{\left(\left|\frac{\mathrm{S}}{\mathrm{B}}\right|-1\right)}$

According to this equation, when the variations of the signals measured by the $\mathrm{CV} \%$ are low, the S/B ratio can also be low and the quality of the assay will still be kept high. Thus, although in principle it is indicated that the S/B ratio is recommended to be higher than 2 ( Table 2), an assay with low variability (for instance with a CV of $5 \%$ for both signals) will result in an assay with a $Z^{\prime}$ of 0.55 , even if the S/B is only 2 . The measurement of these parameters is crucial to identify the best experimental conditions, but also once the assay is developed, they also allow for tracking any unexpected change in performance during the assay implementation stage. Thus, during screening campaigns, $Z^{\prime}$, along with the other statistical parameters, should be calculated for every screened plate. It has been demonstrated that although $\mathrm{Z}^{\prime}$ and SW measure the same properties of the assay, that is, assay 
Table 2 Statistical parameters needed to characterize the performance of HTS assays.

\begin{tabular}{|c|c|c|c|c|}
\hline Parameter & Equation* & Target value & Comments & Reference \\
\hline $\begin{array}{l}\text { Screening window } \\
\text { coefficient }\end{array}$ & $\mathrm{Z}^{\prime}=1-\left(\frac{3 \mathrm{SDmax}+3 \mathrm{SDmin}}{|\mu \max +\mu \min |}\right)$ & $0.5-1.0$ & $\begin{array}{l}\text { Takes into account the means as well as the dispersion of } \\
\text { the assay signals. } Z^{\prime} \text { is measured only with controls; } Z \text { is } \\
\text { measured in the presence of library compounds. }\end{array}$ & [20] \\
\hline Signal to noise & $\frac{\mathrm{S}}{\mathrm{N}}=\frac{\mu \max -\mu \min }{\sqrt{\mathrm{SDmax}^{2}+\mathrm{SDmin}^{2}}}$ & $\begin{array}{l}\text { The higher, the } \\
\text { better }\end{array}$ & $\begin{array}{l}\text { Calculated using only control compounds; measures } \\
\text { how robustly maximum and minimum signals can be } \\
\text { differentiated }\end{array}$ & [21] \\
\hline Signal to background & $\overline{\mathrm{S}}=\frac{\mu \max }{\mu \min }$ & $>2$ & $\begin{array}{l}\text { Calculated using only control compounds: ratio of the } \\
\text { maximum and minimum signal means. If the CVs of the } \\
\text { signals are under } 10 \% \text {, the S/B can be lower. }\end{array}$ & [20] \\
\hline $\begin{array}{l}\text { Coefficient of varia- } \\
\text { tion of the signals }\end{array}$ & $\mathrm{CV} \%=\frac{\mathrm{SD}}{\mu} * 100$ & $<15 \%$ & $\begin{array}{l}\text { Indicates the variation of the signals and can be calcu- } \\
\text { lated to compare signals between plates and days. }\end{array}$ & - \\
\hline $\begin{array}{l}\text { Coefficient of varia- } \\
\text { tion of the assay }\end{array}$ & $\mathrm{CVA} \%=\frac{\mathrm{SD} \max }{\mu \max -\mu \min } * 100$ & $<20 \%$ & $\begin{array}{l}\text { The calculation can be applied when } S D_{\min } \text { is lower or } \\
\text { equal to } S D_{\max } \text {. }\end{array}$ & [22] \\
\hline Signal window & $\mathrm{SW}=\frac{\mu \max -\mu \min -3(\mathrm{SD} \max +\mathrm{SD} \min )}{\mathrm{SD} \max }$ & $>2$ & $\begin{array}{l}\text { Indicates the significant signal between maximum and } \\
\text { minimum signals, which is used to characterize the dy- } \\
\text { namic signal ratio of the assay. }\end{array}$ & [20] \\
\hline
\end{tabular}

signal differences and variability, $Z^{\prime}$ is still a better choice [22]. In our opinion, a more systematic utilization of these parameters in natural product screens will be a highly beneficial practice for the field.

\section{Examples of Specific Problems Encountered During the Development and Implementation of Screening Assays of Natural Products}

Optimization of conditions related to the assay protocol When optimizing and automating an assay it is essential to define key aspects of the different assay protocols, i.e., the steps and processes that are to be performed. This helps in identifying the potential bottlenecks prior to initiating the automation trials, as well as other potential limiting steps [23,24].

Fully automated systems are capable of performing full assay procedures unattended, from the test compound management through the sample preparation and sample analysis to the data processing. Usually, they utilize a centralized robotic arm, which integrates compound libraries, several liquid handling stations, analytical devices, plate incubators, and stackers to the system. These systems are best suited for high compound numbers assayed with fairly simple protocols. On the other hand, semiautomated systems comprising a single liquid handling workstation that may be used in combination with a liquid dispensing unit are more flexible for manual interruptions and reprogramming, and therefore are usually used in executing sections of more challenging assay protocols. An example of a semiautomated protocol in comparison with a manual protocol is presented in - Fig. 3 and further detailed in 0 Fig. 4. These semiautomated approaches are generally more accessible to academic researchers as they may not require massive infrastructure investments and are therefore less costly to implement.

Assay protocols (in semi- or fully automated systems) taking into account LUO thinking helps to provide an understanding of the relationship between the engineering theory and performance of actual experimental laboratory operations [25]. A specific sequence of unit operation is called a "process" ( Fig. 4) and may include one or several individual operations referred to as steps (e.g., the addition of cell suspension, removal of culture medium, incubation, washing or staining steps). This practice improves the project planning, quality, and integrity of assay protocols, and assures valid interpretation of results from data analysis.

Incubation steps do not typically change between manual or automated assays, and generally the only precaution would be to ensure that there is enough space in the incubators to accommodate the larger amount of plates that may be generated in an automated assay. On the contrary, the liquid handling is probably the most demanding aspect that needs to be addressed, as it highly affects the quality of the results obtained, and therefore the liquid handling parameters have to be adjusted to acquire acceptable precision without interfering with the assay system. Some examples are presented in $\bullet$ Table 3.

Critical steps concern general tolerance of the targets to mechanical stress caused by pipetting, the dispense speed of all components (e.g., too high of a dispense speed could cause the fluid forces to interfere with fixation of cells or proteins), removal (i. e., aspiration) of the supernatant after fixation, and contamination hazards. Contaminations should be carefully detected and minimized by choosing the most appropriate tips and liquid handling settings for each reagent [26]. On the other hand, the mixing efficiency is dependent on the correct combination of liquid volume and method used. When working with cells, it must be remembered that stirring too vigorously may cause disruption and impair functionality. Evaporation of liquids may become a problem during prolonged incubations (if the plates cannot be sealed). Cellular studies are normally run at $+37^{\circ} \mathrm{C}$, which promotes evaporation. The assay volume determines the plate format and the choice of liquid handling device [27].

By automating the assays, the number of variables that can be controlled increases significantly to detail levels that are not possible to achieve by even the most skilled researchers. Specific variables, such as the distance from the bottom of the well at which 


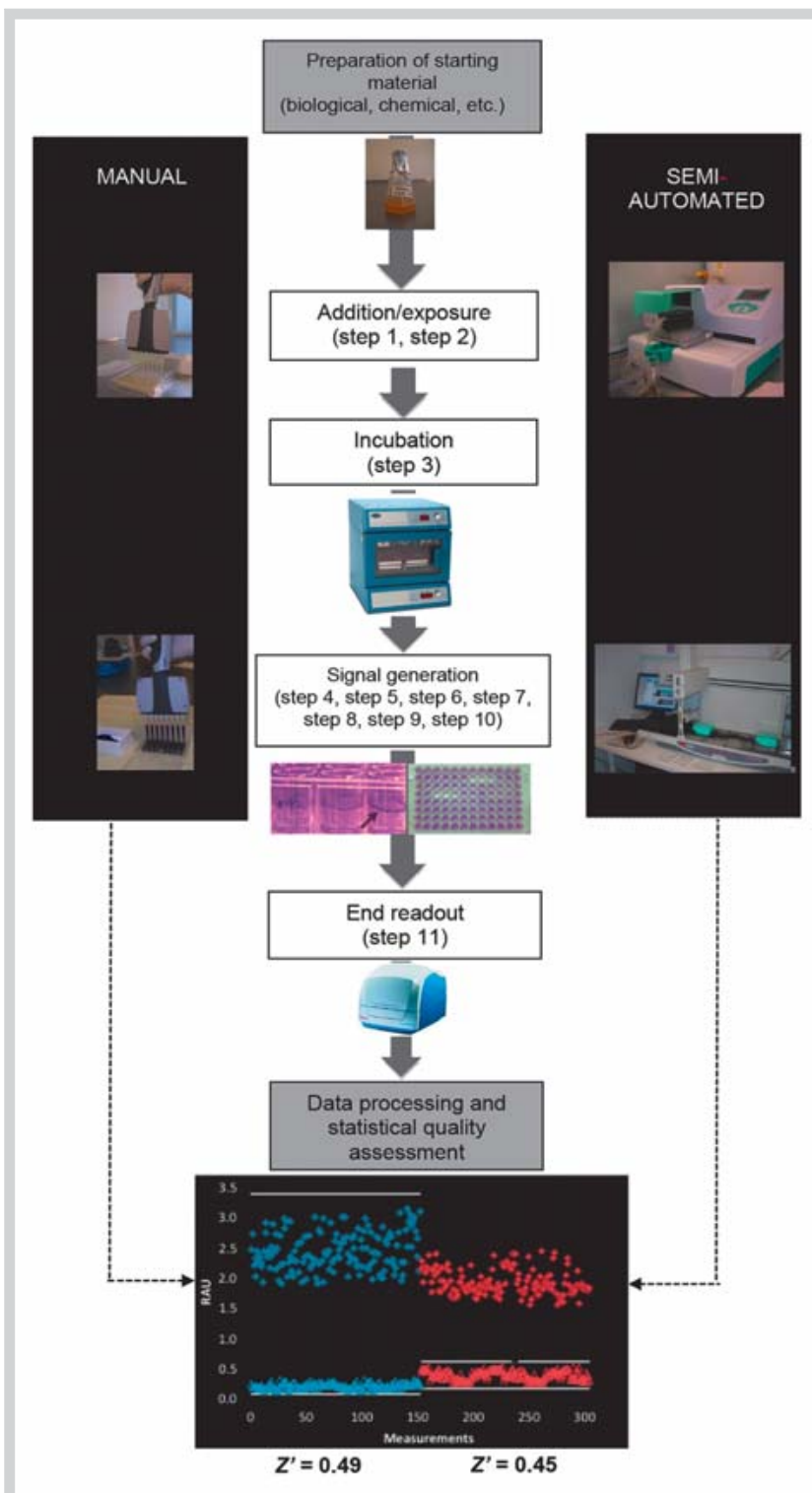

Fig. 3 General view of a typical protocol flow, exemplified with a manual vs. semiautomated comparison of an antimicrobial assay.

the pipette tip is to be positioned in every dispensed step, the dispensing or aspiration speed, or the blowout technique, would be impossible to control manually [27]. Fine-tuning and controlling these variables may in some cases not necessarily translate into an assay that performs better, but it does generally result into an assay with better reproducibility from plate-to-plate and day-to-day, as exemplified in [28].

\section{Detection and elimination of interferences during HTS implementation}

Interferences due to colloidal aggregation: Colloidal aggregation occurs via self-association of organic molecules in aqueous buffer solutions and around 95\% of hits in screening campaigns have been attributed to unspecific, aggregation-based inhibitors [29]. The widespread recognition of colloidal aggregation as a main cause for the occurrence of false positives is greatly attributed to the work of Shoichet and coworkers (see references below [2934]). They established that many nonspecific inhibitors or "heavy hitters" self-associate in biochemical buffers, forming spherical particles of various diameters $(300-1000 \mathrm{~nm})$ that are detectable by DLS and TEM.

Criteria for compounds to be deemed aggregators have been proposed to include time-dependence inhibition of targets, quick inhibition reversal (within seconds) upon the addition of detergents, inhibition being strongly dependent on experimental parameters (e.g., $\mathrm{pH}$, enzyme concentration, protein concentration, and ionic strength), and the occurrence of steep concentrationresponse relationships [30,31]. Because of this, increased Hill coefficients are generally thought to be reliable predictors of aggregation-based inhibition [29]. Aggregators have been postulated to directly interact with target proteins causing partial protein denaturation [32] or to sequester proteins leading to a reduced accessibility of the substrate [33]. However, the exact molecular mechanisms taking place are still being investigated. At a typical screening concentration of $5 \mu \mathrm{M}$, about $1-2 \%$ of compound libraries with "drug-like" properties have been estimated to behave as aggregators, and at $30 \mu \mathrm{M}$ that percentage has been shown to increase to $19 \%$ [34]. In both scenarios, the prevalence of aggregators is relevant when considering the typical hit ratios $(<1 \%)$ of screening campaigns.

Natural products were within the aggregate formers that were first reported by Shoichet's laboratory around 10 years ago. McGovern and Shoichet [31] analyzed 15 nonspecific kinase inhibitors and showed that eight of them were aggregate formers, from which three molecules were of natural origin ( Fig.5). They were the very well-known flavonoid quercetin, indirubin, which is present in Indigofera tinctoria and claimed to be an antitumor [35,36], and rottlerin, another phenolic compound naturally existing in Mallotus phillipinensis ("Kamala" tree) and reportedly active as an opener of potassium channels (BKCa++) [37]. Subsequent investigations confirmed these results and established the promiscuous enzymatic inhibition profiles of these natural compounds $[38,39]$.

Recently, a systematic study of the occurrence of colloidal aggregation among purified natural molecules was performed [40]. These authors screened a small but representative subset of natural phenolic compounds (117) and found that the proportion of aggregating compounds was around $12 \%$ when they were tested at a concentration of $10 \mu \mathrm{M}$. They showed that flavonoids were more aggregation prone than other phenolic compound classes such as coumarins and organic acids. In fact, all of the studied flavonoids (23) formed DLS-detectable aggregates in at least one of four different tested conditions. The occurrence of aggregates, however, did not automatically translate into unspecific inhibition and only two flavonoids (quercetin and rhamnetin) were identified as promiscuous [40]. The study, however, gave the foundations for another equally plausible scenario, that aggregation could also lead to false negatives by reducing, for instance, the concentration of the compounds available in the solution. Based on all these findings, a necessity has surged of acknowledging aggregate formation as a likely source of either false or negative hits when screening natural compound collections.

A first step to exclude false positives after performing a primary screening campaign is to check if any of the identified natural hits have been previously flagged as aggregators. For flavonoids, we recommend checking on the list compiled in [40] (available at: http://www.mdpi.com/1420-3049/17/9/10774), while for other types of natural compounds, the list of aggregators that is maintained by Shoichet's laboratory could be consulted (available at: http://shoichetlab.compbio.ucsf.edu/take-away.php). 


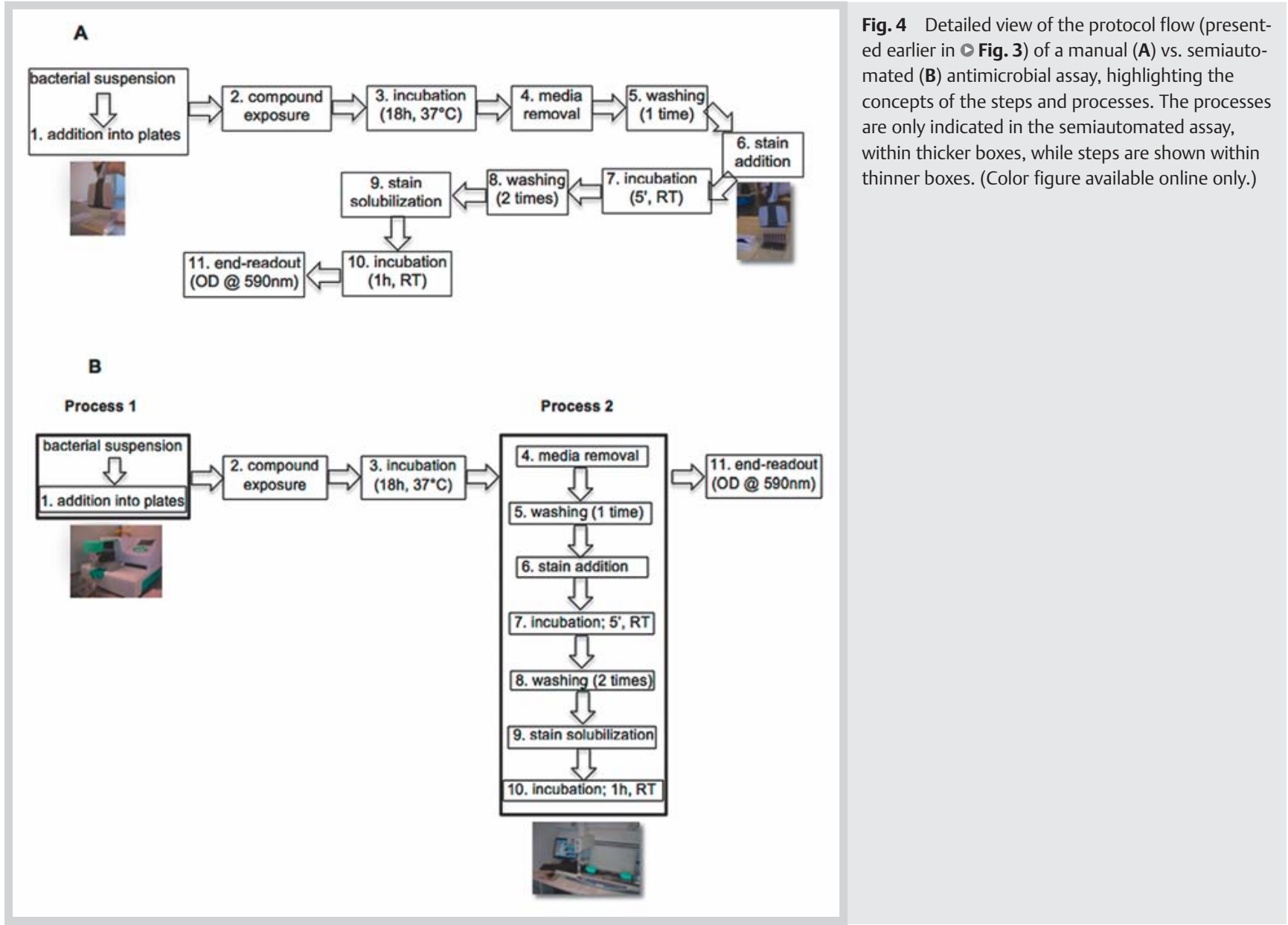

Table 3 Some key liquid handling parameters to be taken into account when performing an assay and troubleshooting strategies, exemplified with the semi-

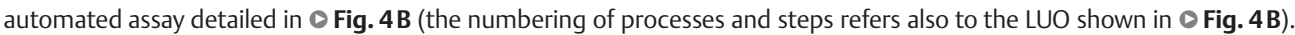

\begin{tabular}{|c|c|c|c|c|}
\hline Process & Step & Potential problem & Critical parameter* & Solution \\
\hline \multirow[t]{3}{*}{1} & \multirow[t]{3}{*}{1} & Suspension uniformity & SH & - Prior shaking (and systematic, during protocol, if needed). \\
\hline & & Contamination & TR & - Tip refreshing steps need to be added. \\
\hline & & Mechanical stress on cells & DS & Fine-tuning of the tolerable dispensing speeds. \\
\hline \multirow[t]{3}{*}{2} & 4 & $\begin{array}{l}\text { Cellular detachment during } \\
\text { media removal }\end{array}$ & AS, TH & $\begin{array}{l}\text { Aspiration without touching the bottom of the wells (for } \\
\text { attached cells). } \\
\text { - Aspiration speed and tip height need to be optimized. }\end{array}$ \\
\hline & 5 & $\begin{array}{l}\text { Cross-contamination within } \\
\text { the plate }\end{array}$ & TR & - Tip refreshing steps need to be added. \\
\hline & 6 & $\begin{array}{l}\text { Stains outside the reaction } \\
\text { wells }\end{array}$ & TH & $\begin{array}{l}\text { Dispensing height has to be carefully optimized. } \\
\text { - Tip refreshing steps may be added. } \\
\text { - Potentially overstained wells are tracked. }\end{array}$ \\
\hline
\end{tabular}

* Parameter clarification: SH - shaking, TR - tip refreshing, DS - dispensing speed, AS - dispensing speed, TH - tip height

In biochemical assays, a simple experimental way to preclude interfering aggregators is by retesting their inhibitory effects in the presence of non-ionic detergents. If the inhibition is significantly attenuated by small amounts of non-ionic detergent, the compound is likely to act via aggregation. Detergents (0.01-0.1\%) have been proposed to disrupt aggregate formation as well as dissociate the protein-aggregate interaction. Feng et al. [29] performed a large detergent-based campaign with more than $70 \mathrm{k}$ molecules and concluded that inclusion of $0.01 \%$ Triton X-100 effectively reverses the promiscuous inhibition caused by more than the $95 \%$ of the aggregators. This strategy can be optimized to perform well in either lower throughput (i.e., cuvettes or 6well plates) or higher throughput formats (i.e., 96-, 384-, or 1536-well plates). Other detergents such as Tween-20, CHAPS12, saponin 10, and digitonin have been shown to be applicable as well [41]. Experiments can be run separately in the presence and absence of the detergent. A precautionary note is that when using the detergents, they should be preferably added to the buffer before any other component. The introduction of detergents in many different assay formats has been proven possible without compromising the assay quality [41]. In assays that cannot tolerate non-ionic detergents, for instance, in cell-based assays, 


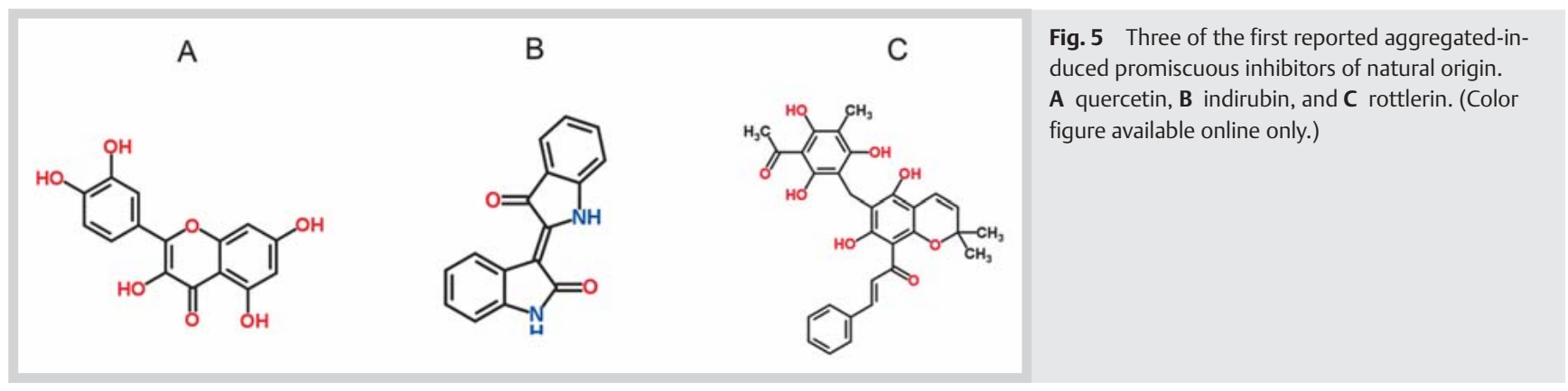

a suggested possibility has been to use $1 \mathrm{mg} / \mathrm{ml}$ of bovine serum albumin (BSA) instead [30], but this molecule can sometimes sequester non-promiscuous hits [34] or cause other types of interferences [42].

Although the detergent sensitivity concept is widely applied for excluding unspecific inhibitors, other methods have been implemented that allow a direct and noninvasive quantification of the formed aggregates. Among them, high-throughput screening assays based on SPR using Biacore technology [39] and PC biosensor microplates [43] have been reported. From these studies, it has also become clear that some of the interactions between aggregates and protein targets are spontaneously reversible and this can add additional complexity to the process of flagging and removing aggregators from natural libraries.

Other features of the functional behavior of hits can similarly help in distinguishing the "false" (or promiscuous) from the "true" ones. For instance, if an inhibitor is found to display a competitive kinetic mechanism, this compound can be regarded as less likely to be an aggregator [34]. This consideration is based on the structural similarities that competitive inhibitors typically share with the substrate and their ability to recognize specifically the catalytic sites, which differs from the unspecific nature of the aggregates-induced inhibition. On the other hand, the preservation of inhibitory activity after spinning compounds for several minutes in a centrifuge also indicates that aggregates are not being formed.

Apart from experimental approaches, attempts have been made to characterize the physical-chemical properties of the aggregators on the hopes of applying in silico calculations to predict the aggregation potential. Two features have been suggested to potentially distinguish between aggregators and non-aggregators: clog $\mathrm{P}$ and aqueous solubility. Based on these features, from of a set of 111 compounds, a valid distinction in more than $80 \%$ of the cases was done, with aggregators exhibiting higher clog $\mathrm{P}$ and lower aqueous solubility $[44,45]$. A better prediction (correct in over $90 \%$ of cases) has further been achieved by a more complex recursive partitioning model [44].

We have, for instance, mapped the chemical space occupied by aggregators and non-aggregators using ChemGPS-NP, a freely available chemography tool $[46,47]$, applicable to natural compounds ( $\bullet$ Fig. 6, unpublished results). The used aggregators and non-aggregators (96 compounds) have been obtained from the publicly available repositoire of Shoichet's laboratory, mentioned earlier. Regions of the chemical space, as defined by a combination of descriptors characterizing molecular size (PC1), aromaticity (PC2), and lipophilicity (PC3), have been seen to overlap between aggregators and non-aggregators. As pointed out by other authors [44], the selection of proper descriptors and development of simple models that could accurately predict the aggre- gating behavior of compounds is a challenging task. We believe this is an area in which more research needs to be performed in order to facilitate follow-up studies during the reconfirmation stage of a large number of primary hits.

Optical interferences: Crude extracts have a maximized chemical diversity and do not require any purification steps, but in order for the activity to be detected, they often need to be screened at higher concentrations due to the low concentrations of their active components. A major drawback of screening concentrated crude or semi-purified extracts is that color interference, autofluorescence, or light scattering by particulated samples (as those present in lab dust) can occur, which generates false positives and negatives. Similarly, colored and/or autofluorescent pure compounds can cause artifactual results. Indeed, many natural compounds are rigid and planar and possess multiple conjugated aromatic moieties, which increase the probability of endogenous fluorescence [48]. This is the case in widely distributed natural molecules such as coumarins, anthraquinone derivatives (for instance, hypericin, present in the alcoholic extract of Hypericum perforatum) and pigments such as carothenes, chlorophyll, or chlorophyll breakdown products such as phaeophorbide A [49]. Additionally, the aging of samples can result in the formation of degradation products, which can be strongly light absorbing compounds even in the visible range (400-700 nm) [50].

In these cases, the compound spectral properties cause interferences with the light detection step of the screening assay, and they are mostly predominant in assays that are run in absorbance and fluorescence (FI, FP, and FRET) modes [51]. Such interferences are manifested by a typical increase in the background signal of the assay but also by the participation in unwanted FRET with the assay fluorophore [48]. Given that a vast majority of screening assays is nowadays run with absorbance- or fluorescence-based technologies, these issues cannot be ignored. Moreover, the increased use of homogeneous assays also accentuates these problems as the test samples remain in the wells during the entire duration of the assays.

Because these interferences are technology dependent, suggested solutions typically involve changes in the protocols or ultimately in the detection methods. The simplest strategy for dealing with minor optical interferences is to include one step in which the absorbance or fluorescence of the interfering molecules is measured in the absence of any other reaction component, which is then subtracted from the signal detected in the real biochemical or cell-based assay. However, in many cases, the compound fluorescence can be higher than that of the fluorophore, even at relatively low concentrations $(10 \mu \mathrm{M})$ [52], and this strategy is, thus, not sufficient. The problem is additionally aggravated when higher concentrations of extracts or pure compounds $(>10 \mu \mathrm{M})$ are tested in cell-based assays, since different 


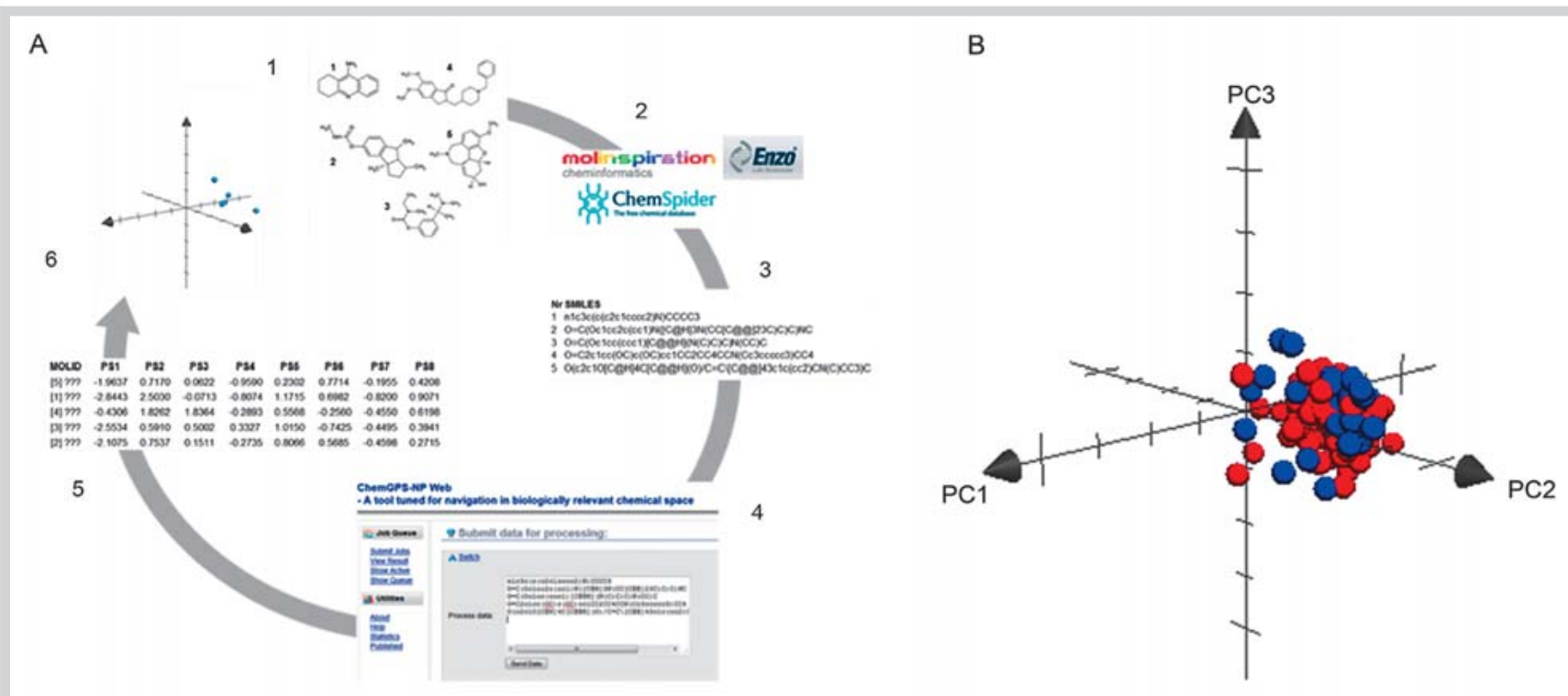

Fig. 6 A Workflow of the in silico process used for mapping of the chemical space of aggregators and non-aggregators. $\mathbf{B}$ 3D representation of the chemical space of aggregators (blue dots) and non-aggregators (red dots), using the Principal Component Analysis (PCA)-based chemical space navigation tool ChemGPS-NP (unpublished results). As schematically represented in
A, the analysis uses 2D descriptors (35) describing the physical-chemical properties of the compounds that are calculated from SMILES. Salts, hydration information, as well as counter-ions are excluded from SMILES. For analysis of the chemical space, the first four dimensions (PC1-PC4) are plotted using the software Grapher 2.1 (MacOS X, US). cell types can display endogenous fluorescence in various conditions. This solution is also not operational for unwanted FRET artifacts, which are more difficult to identify and correct. In the literature, a common bypass of this issue has been to exclude optically interfering compounds from follow-up studies, but in our opinion this strategy hampers the identification of natural scaffolds that could have otherwise held promise as starting points for lead refinement strategies [48]. A better solution is offered by simple mathematical procedures that can be applied to correct for both increases and decreases from the baseline caused by interferences from test compounds, as described in [50]. Another contribution focuses on different strategies that can be applied to tackle this type of interference, specifically in FRET-based assays [53]. However, even if data can be corrected with these procedures, the data would eventually need to be rejected in cases where the interferences result in more than a 2 -fold change in the signal [50].

A second-tier strategy that we can recommend is the utilization of fluorescence assays that rely instead on red-shifted dyes or longer wavelength tracer fluorophores to avoid spectral overlap with organic compounds that absorb in the ultraviolet region or other autofluorescent molecules (such as coumarins). Several dye classes have been developed in recent years with absorption maxima beyond $520 \mathrm{~nm}$, extending to nearly $800 \mathrm{~nm}$, from which it is possible to select for nearly all types of assay applications. The suitability of this approach for natural product screening has been documented. Red-shifted fluorogenic substrates have been shown to reduce interferences during the screening for protease inhibitors from natural extracts, from prokaryote, fungal, and plant sources, as well as pure natural compounds [54]. Also, an FP assay using red-shifted dyes has been developed to screen for kinase inhibitory activity resulting in significantly less interferences from constituents of microbial extracts when compared to a fluorescein-based competitive FP assay or a [ $\left.{ }^{33} \mathrm{P}\right]$ ATP Flashplate assay [55]. However, this strategy is also not exempt of limitations, as it may not prevent the interferences from red- and far-red emitting pigments such as chlorophyll and other naturally occurring porphyrins.

A third strategy for overcoming these limitations is the implementation of methods that entirely preclude the use of chemical labels, otherwise known as label-free. Particularly in cell-based assays, label-free methods rely on impedance-based measurements to detect changes in the electric properties or the passage of ions through the cells. These changes can be brought about by cellular changes in the attachment to electrodes located in dishes, for instance, in 96-well microplates or by the activity of different receptor types (i.e., GPCRs, tyrosine kinase) [56,57]. Beneficial aspects of these methods include that they can be applied without any restriction in colored and autofluorescent samples, they are noninvasive and they offer continuous readouts and a simultaneous view of short- and long-term cellular events with very minimal labor involved. Moreover, because cells are not stained, fixed, or altered in any way at any point, samples can then be interrogated for the presence of metabolites or for other responses using chemical labels. Such an additional interrogation allows for obtaining a multicomponent response from a single culture of cells, which diminishes biological variability. Currently available label-free technologies, for instance, Electric Cell-Substrate Impedance Sensing (ECIS, from Applied Biophysics), Epic System (from Corning), or xCELLigence (from ACEA Biosciences), were originally accepted with a very slow pace in the drug discovery scenario, but over the last ten years they have increasingly attracted interest as their throughput and robustness have increased.

Until now, label-free methods have been shown to be excellent tools for tracking cytotoxic effects, also in the case of natural samples. Investigations have been performed on the cytotoxicity of a large collection of extracts from Bangladeshi traditional medicinal plants against pancreatic and breast cancer cells [58-60]. These studies have followed a tiered screening approach in which 
the first screen is performed in all samples using a label-free PC biosensor, followed by two other follow-up assays using conventional labels (MTT proliferation and caspase 3-induction). Their approach ensures that none of the tested extracts (more than 55 in two of the studies) would be excluded due to interfering optical signals during the first screen. The PC biosensors are located in 96-well microplates and they produce a highly localized shift in reflected wavelength at the site of cellular attachment that is coupled to an image detection system that scans the biosensor surface and has sufficient resolution to monitor the attachment/ detachment of individual cells. Image analysis can be used to study the cellular population of cells in the wells, which can be readily translated to a simple cell count. Using the label-free biosensor assay, researchers have been able to rapidly differentiate and classify the effects on cancer cells of several plant extracts with a previously unknown function $[58,59]$.

In a recent work, Kling et al. 2013 [61] used the ECIS method to screen for the neuroprotective activity of 19 phenolic compounds such as flavonoids, flavonoid metabolites, phenolic acids, and their methyl esters (including several colored compounds) after induction of oxidative stress with tert-butyl hydroperoxide, and compared their output with a conventional cytotoxicity assay, based on an endpoint measurement with the MTT probe. This work documented the benefits of studying neuroprotection mechanisms via the recording of continuous cellular responses with ECIS. The described method was also particularly advantageous for dealing with compounds like quercetin or kaempferol, which have been shown to interfere with the performance of redox probes, such as MTT [62-64].

In our laboratory, studies have been performed on the cytotoxicity of several natural extracts, and one of them (coded NP1, unpublished results) has offered a challenge, as this plant extract interferes with many commonly used viability assays. For instance, NP1 reduces resazurin in the absence of cells, likely due to redoxactive constituents, and it also increases the signal of calcein and ethidium homodimer 1 (EthD-1; components of the commercial LIVE/DEAD viability/cytotoxicity kit), which to a certain extent could be explained on the basis of the extract's autofluorescence. Thus, NP1 can cause an overestimation of the cell viability, leading to false negative results.

These problems are circumvented when the label-free ECIS assay is applied for the cytotoxicity measurement of crude extracts. In o Fig. 7, the impedance curves recorded with ECIS showed an overall concentration- and time-dependent cytotoxicity of NP1 (unpublished results). In this assay, increases in the impedance are associated to cellular attachment while decreases are caused by toxic insults that can result in the loss of the cellular integrity of the cellular monolayer formed on the ECIS electrodes, as exemplified by the addition of NP1 (200 $\mu \mathrm{g} / \mathrm{ml}$, O Fig. 7).

Specific advantages of using ECIS in this type of study are readily noticeable. The first one is related to the continuous nature of the cellular responses that are measured. For example, after adding NP1 (100 $\mu \mathrm{g} / \mathrm{ml}$, O Fig. 7), a sudden decrease of about one-fourth of the impedance values compared to untreated cells is detected, but within a few hours, a recovery of the cells is recorded and after 40 hours, less than a $10 \%$ decrease of the impedance values is detected. This indicates that early toxic events triggered by NP1 are temporarily buffered by the cells, which would have been overlooked in a conventional cytotoxicity assay performed only at a single time point (for instance, at 48 hours). Another advantage of the ECIS studies is the possibility of recording delayed cytotoxicity events. In $\odot$ Fig. 7 , it can be seen that after 48 hours, the

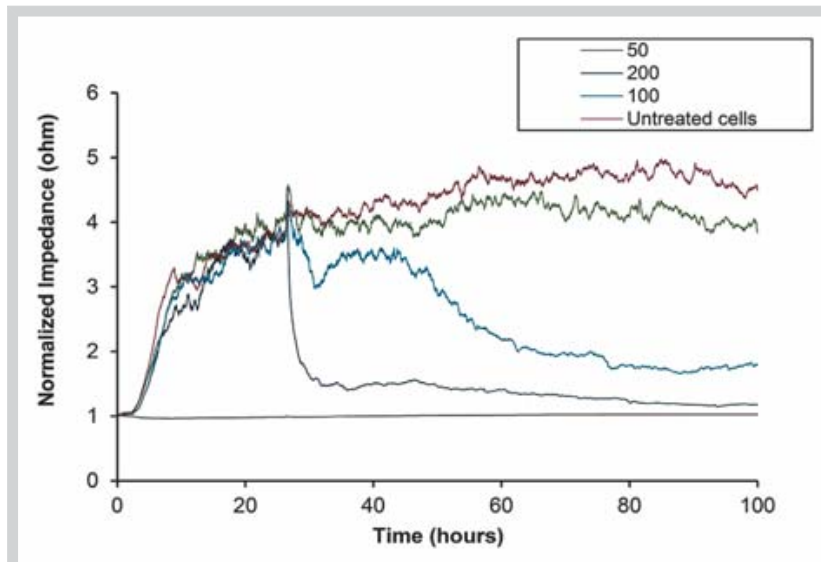

Fig. 7 Impedance changes recorded by ECIS in GT1-7 cells treated with a crude plant extract (coded NP1) at different concentrations (50, 100, $200 \mu \mathrm{g} / \mathrm{ml}$ ). ECIS instrumentation model Z (Applied Biophysics) was used. 8 W1E electrodes were pretreated with $10 \mathrm{mM}$ of cysteine as recommended by the manufacturers. Electrodes were filled with $400 \mu$ of DMEM, and impedance recorded at $16 \mathrm{kHz}$ every 60 seconds for 1 hour. Cells $(400 \mu \mathrm{l}$, $4 \times 10^{5}$ cells $/ \mathrm{ml}$ ) were then added and impedance continued to be measured. Twenty-four hours after adding the cells, $40 \mu$ of the medium was replaced by $40 \mu$ l of the NP1 or medium in the untreated control wells.

cells can tolerate NP1 $(100 \mu \mathrm{g} / \mathrm{ml})$ with less than a $25 \%$ decrease in impedance values compared to untreated cells. However, as time proceeds, the impedance steadily drops and a clear toxicity is seen after 72 hours with an over $50 \%$ decrease in impedance values. This delayed toxicity would have also been undetected had the measurements been conducted only using acute cytotoxicity assays.

Label-free methods, on the other hand, are not exempt of disadvantages. Among them are the difficult interpretations of the results and the lack of full understanding of the biological significance of some measured signals $[65,66]$. These two elements seem to relate to the biophysical nature of the measured responses that are mostly associated with complex physical responses and are not always fully elucidated from a biochemical perspective. Also, the utilization of these methods by the academic community has been hampered by their high consumable costs. However, upon identifying natural compounds or extracts with optically interfering compounds, these methods could offer a new alternative for further investigation of some biological activities. Based on this, it is our view that more dedicated research in label-free bioactivity screens of natural products will benefit drug discovery.

Interferences due to the meniscus effect: Optical signals can also be attenuated by reasons that are not associated to the optical properties of the compounds, but instead by the surfactant-like physical properties. Although these interferences are not as frequent as the ones described above, some natural samples containing surfactants such as saponins can cause a deepening of the meniscus of the liquid in microtiter well plates, which results in a decrease of the path length in the liquid column that can reduce the amount of absorbed light being measured through the liquid column. This interference typically results in a lower signal when running absorbance-, fluorescence-, and luminescencebased assays in top-reading instruments. Methods for correcting them have been described recently [50]. 


\section{Antibacterial Screening of Natural Products As a Case Study \\ $\nabla$}

Having discussed general aspects of the development of screening assays and implementation stages, we will now focus on an area in which natural products offer a successful case study: antibacterial drug discovery. Despite the immense impact that antibacterial drugs have had on overall life expectancy and quality, bacterial infections remain a persistent health burden both in industrialized countries and the third world [67]. Considering the aspects of both the bacterium and the host, the two obvious challenges in treating bacterial infections are the selection of resistant mutants and the increasing number or opportunistic infections among immunocompromised persons $[68,69]$.

Antibacterial agents have been the focus of natural product research for several decades, and continue to be among the most widely screened biological activities among natural product scientists. One evident reason for this is the success of natural products as antibacterial drugs and drug leads. According to a recent report by Cragg and Newman [4], 75\% of all new small molecule antibacterial agents approved by the FDA between 1981 and 2010 were of natural origin. However, antibacterial drug discovery in general is currently a matter of major concern due to low success rates, and several pioneers and professionals in the field have pointed out the need for reevaluating the screening strategies to reconcile our research practices with the demands set by resistance, persistence, and opportunistic infections [70-73]. The wide variety of antibacterial assays reflects the extensive efforts to identify new drug molecules within this therapeutic. The rest of this section aims to give a short overview of the different assays available, highlighting some of the points discussed in the previous sections.

\section{Phenotypic assays for bacterial growth inhibition}

The classical antibacterial screening strategy has relied on exposing bacterial cultures grown on agar plates to test samples and measuring the inhibition zones (areas with no bacterial growth) around the samples. This methodology was used during the discovery of virtually all antibiotics during the 1960s, many of which still form the basis of our antibacterial drug arsenal [74]. It is still widely used for low-throughput bioactivity studies and has been recently applied, among other studies, to the evaluation of plant extracts selected for ethnobotanical use in different areas $[75,76]$. The popularity of the this assay for screening the activities of plant extracts most likely reflects tradition rather than rational selection of an assay method least prone to interference with the test material. As recently pointed out by Gertsch (2011), the scientific knowledge needed for choosing the biologically most relevant means for studying the biological activities of complex plant-based mixtures, in which synergism, for instance, could take place, is currently missing to a large extent [77]. The ethnobotanical studies typically involve some tens of samples in maximum, reflecting the limitations that the method has for screening purposes. Since the assay endpoint relies on a visually measurable inhibition zone, the assay requires large amounts of reagents and laboratory space, and suffers from a slow and labororiented readout because of the need for manual determination of the zones of inhibition. Nevertheless, the assay can be miniaturized and automated by using image-based screening platforms capable of quantifying the bacteria-free zones on a much smaller scale $[78,79]$.
To meet the needs set by increasing sample numbers, various microtiter plate-based assay formats have been established, relying on the measurement of bacterial biomass or metabolic activity of bacteria growing as a suspension [80]. Considering time and reagent consumption per sample, such assays are much better suited for large sample collections or projects with bioassayguided isolation of the active ingredients within extracts, as shown by the recent identification of novel broad-spectrum antibacterial agents among natural products using a pH-dependent metabolic dye [81] or a study on Pseudomonas aeruginosa using optical density measurements [82]. Integrating such methods with other technologies, such as microfluidics and fluorescenceaided cell sorting, has also allowed for the development of sophisticated platforms of bacterial viability evaluation [83].

In antibacterial assays, potential sources of interference are dominated by the colored or fluorescent nature of the tested samples, since all classical viability probes rely on photometric or fluorometric readouts within the spectral area that is also covered by natural products and other small molecules, as discussed earlier. One practical means for overcoming this type of interference is by the baseline measurement of each sample prior to the bacterial growth phase, allowing for the elimination of potentially increased background values in each sample separately. Another potential source of compound-borne interference is the ability of some redox-active compounds to directly convert viability dyes whose conversion to a colored or fluorescent form relies on cellular oxo-reductive metabolism. If such a feature is suspected in the antibacterial assay, we recommend performing counter-screenings in the absence of living cells to detect any direct interactions between the dye and the samples to be tested.

From a biological point of view, the major difference between the above-mentioned microtiter plate-based assays and the classical agar culture assays is the state of bacterial community. The microtiter plate-based assays rely on liquid cultures of planktonic bacteria, in which the cell population is maintained in a logarithmic growth phase. In contrast, bacteria grown on agar plates grow attached to the solid medium surface, which, as discussed below, is considered to represent a biologically more relevant growth state of most pathogenic bacteria.

More focused or hypothesis-driven phenotypic screening assays have been set up by using reporter gene assays with fluorescent or luminescent bacterial strains. Depending on the specific setup, the reporter systems are used to identify inhibitors of, e.g., bacterial transcription [84] or translation [85]. Technically speaking, the time span of these assays are typically much shorter than in classical growth inhibition assays, primarily for two reasons. First, changes in transcription, translation, or other similar events can be detected within a few hours when the monitored event is the direct target of the inhibitor in question. Second, the use of fluorescent and luminescent reporter enzymes typically yields readouts with a good $\mathrm{SW}$, providing the basis for a good assay performance even with short exposure times. The prerequisite for achieving biologically meaningful screening assays by this approach is the validation of the reporter gene insertion stability within the bacterial genome and characterization of the growth kinetics of the recombinant strain.

Similar to pure growth inhibition assays, autofluorescent natural products may interfere with fluorescent readouts, while luminescent reporter genes do not suffer from such interferences. However, since the light generated by luciferases originates from an enzymatic reaction, any inhibitor, activator, or stabilizer of the reporter enzyme can suppress the amount of light to be detected 
and may thus be identified as a false positive in any screen utilizing the reporter [86]. The proportion of firefly luciferase inhibitors in an unbiased chemical library has been estimated to be approximately $3 \%$ [87], and screening data on luciferase inhibitors has also been made publicly available (PubChem AID 411). To control false positives or negatives due to reporter enzyme-directed effects, consulting such publicly available data, testing the activity of hit compounds on purified luciferase, and performing a hit confirmation are our recommended approaches. Also, it is worth to keep in mind that luciferase-inhibiting natural compounds may still exhibit genuine bioactivities not related to this property. For instance, the extensively studied polyphenol resveratrol has been reported to inhibit firefly luciferase [88] and should therefore be treated with special caution in luciferasebased assays, but certainly not all biological activities reported for resveratrol can be attributed to luciferase-related artifacts. Therefore, we do not consider excluding compounds like resveratrol from natural product libraries necessary or even beneficial. With respect to intracellular bacteria, image-based HCS assays provide a more efficient and informative way to alleviate the laborious assay protocols often involving the readout of the results under a microscope. Simultaneous detection of bacterial replication centers and host cell components have been described for different bacteria [88]. While most bioactivity screens utilizing the manually determined intracellular bacteria load have involved less than one hundred samples (e.g., $[89,90])$, the screening of 57000 compounds with an HCS assay using GFP-expressing Mycobacterium tuberculosis and RAW macrophages as host cells illustrates the possibility to potentially increase the throughput associated with HCS platforms [91].

The improved information content achieved by HCS applications in an antibacterial assay context refers typically to either information on bacterial antigen localization, detection of specific stages in the bacterial life cycle, or simultaneous detection of host cell viability. While the two former cases may provide significant benefits in a hypothesis-driven or targeted antibacterial screening, the latter aims to simply exclude toxic compounds without the need for additional counter-screens. Even though the concentration-dependent effects of different antibiotics on bacterial cell morphology are relatively well-known, increasing primary screen information content by achieving mechanistic data from image-based screening platforms is limited by the resolution of fluorescent microscopes due to at least one order of magnitude smaller bacterial cell size compared to mammalian cells. However, the recent work by Peach et al. [92] described the development of a software platform capable of predicting mechanisms of action of antibacterial ingredients within marine natural product extracts using Vibrio cholerae cell morphological phenotypes and a training set of antibiotics with known mechanisms of action.

The nematode worm Caenorhabditis elegans has become an established model for studying bacterial pathogenicity in a whole organism and, more recently, also gained popularity as an in vivo screening model for antibacterial activity [93]. The ability of C. elegans to feed on pathogenic bacteria and the death of the organisms upon the infection has formed the basis for straightforward assays detecting worm viability using live/death dyes. With its size of $1 \mathrm{~mm}$, C. elegans can be dispensed with liquid handling instruments. Academic screens using a C. elegans rescue assay with tens of thousands of compounds and natural product extracts have been carried out on Enterococcus, Pseudomonas, and Vibrio species $[94,95]$. The power of $C$. elegans rescue assays in antibacterial screening is obvious for two reasons: i) it detects not only inhibitors of bacterial replication but also compounds suppressing in vivo virulence of the target bacterium, and ii) it can exclude compounds showing acute toxicity on the host organism or pharmacokinetic properties limiting the penetration to target tissues [93]. While HCS and other phenotypic platforms are, in some cases, limited by the sample numbers they can be adopted to, many academic screening campaigns involve small or medium size collections of compounds or extracts that can easily be tested in assays with a high information content and, thus, we encourage the academic natural product research community to take full advantage of this aspect.

\section{Target-based approaches for identifying inhibitors of bacterial growth}

Screening of classical antibiotic targets: Clinically approved antibacterial drugs target only a few bacteria-specific structures, such as ribosomes and enzymes essential for cell wall or folate biosynthesis. Target-based screening assays, both for ligand-binding and functional enzyme assays have been described for all these targets and can be readily used for screening ( $\bigcirc$ Table 4). A primary advantage of these targets is that their essential nature for bacterial growth is well validated and the proteins in question have been extensively characterized by biochemical and structural biology means. Many of these proteins and assay reagents are also readily commercially available (for representative examples, see references in $\odot$ Table 4).

Many of these targets have been exhaustively tracked by chemical inhibitor screens, and scaffolds of known ligands have been widely diversified by medicinal chemists, reflecting the fact that the vast majority of newly approved antibiotics during the past decades are derivatives or analogues of previously known drugs $[71,73]$. However, previous and recent work on these targets illustrate that the target-based approach can also be used for successful identification of inhibitors or modulators that are structurally unrelated to the known antibiotics. Examples in this respect include the identification of several non-beta lactam structured ligands of Neisseria gonorrhoeae, a penicillin-binding protein, and anziaic acid isolated from Hypotrachyna sp. as an inhibitor of topoisomerase 2 (an enzyme also known as DNA gyrase) [96].

Despite the massive amount of work put into the known targets, only a limited number of drug molecules suitable for clinical use are available for certain targets. For example, mupirocin, a monoxycarbolic acid derivative originally isolated from Pseudomonas fluorescens, remains the only clinically approved inhibitor of aminoacyl-tRNA synthetase (ARS; a family of enzymes involved in bacterial tRNA biosynthesis), but its use has been limited to topical applications such as wound infections due to its properties not being suitable for systemic use [97]. Trimethoprim, on the other hand, remains the only approved antibacterial drug targeting dihydrofolate reductase [98]. Identifying new molecules chemically unrelated to the previously used drugs can be considered one valuable approach to broaden our antibacterial drug arsenal.

However, the usefulness of mupirocin and trimethoprim, as well as most other antibiotics in clinical use, is limited by the emergence of resistant bacterial strains, in part due to the accumulation of low-affinity variants of the target protein. Screening of the wild-type enzymes and bacterial strains is therefore not a sufficient means for identifying clinically useful compounds for further development. Instead, including the low-affinity mutants 
Table 4 Some examples of assays for antibacterial targets with existing antibiotics that are in clinical use.

\begin{tabular}{|c|c|c|c|c|}
\hline Target & Assay format & Detection mode & Application & Reference \\
\hline $\begin{array}{l}\text { Penicillin-binding } \\
\text { protein }\end{array}$ & Competitive binding assay & $\begin{array}{l}\text { Fluorescence Polarization; labeled } \\
\text { penicillin as competing ligand }\end{array}$ & $\begin{array}{l}\text { Screening of pooled small mole- } \\
\text { cules }\end{array}$ & [136] \\
\hline Ribosome & Binding assay & $\begin{array}{l}\text { Fluorescence quenching of a fluoro- } \\
\text { phore-labeled ribosome }\end{array}$ & $\begin{array}{l}\text { Screening of a small set of soil } \\
\text { microbe extracts }\end{array}$ & [137] \\
\hline Ribosome & Competitive binding assay & Fluorescence, labeled neomycin & $\begin{array}{l}\text { Characterization of aminoglyco- } \\
\text { side binding }\end{array}$ & [138] \\
\hline Ribosome & Competitive binding assay & $\begin{array}{l}\text { FRET; coumarin conjugated aminoglyco- } \\
\text { side and ribosome }\end{array}$ & $\begin{array}{l}\text { Characterization of aminoglyco- } \\
\text { side libraries }\end{array}$ & {$[139,140]$} \\
\hline Topoiso-merase & Enzyme inhibition assay & $\begin{array}{l}\text { Fluorescence Intensity; fluorophore- } \\
\text { labeled oligonucleotide as substrate }\end{array}$ & $\begin{array}{l}\text { Screening of small molecule and } \\
\text { NP extract libraries }\end{array}$ & [96] \\
\hline $\begin{array}{l}\text { Dihydrofolate } \\
\text { reductase }\end{array}$ & Enzyme inhibition assay & $\begin{array}{l}\text { Fluorescence Intensity; NADH levels } \\
\text { determined with resazurin }\end{array}$ & $\begin{array}{l}\text { Screening of small molecules/ } \\
\text { synthetic and natural }\end{array}$ & [141] \\
\hline $\begin{array}{l}\text { Dihydropteroate } \\
\text { synthase }\end{array}$ & Enzyme inhibition assay & $\begin{array}{l}\text { Radiometric; substrate and product } \\
\text { separation by TLC }\end{array}$ & Screening of pyrimidine libraries & [142] \\
\hline
\end{tabular}

of the protein is recommended to overcome this problem [70]. Other resistance mechanisms, such as compound inactivating enzymes or efflux pumps, can also be included within the screening platforms, which may be of particular benefit when screening plant-derived material. While high-potency growth inhibitors are typically not found among pure compounds isolated from plants, some classical examples of synergistic combinations of compounds found within plant extracts are known [99]. Assay methods and advances in identifying inhibitors of both beta-lactamase enzymes and bacterial efflux pumps have been previously reviewed $[100,101]$ and are, thus, not covered here in more detail.

Screening of novel targets: It is generally thought that finding more potent inhibitors of known targets will not solve the resistance problem in the long run, and huge efforts have been made in order to find new targets for antibacterial discovery. Genomics analyses of pathogenic bacterial species have indicated that there are 100-200 conserved bacterial genes with no close homologues in eukaryotes [71]. The pharmaceutical industry has invested significant amounts of time and resources to validate the essentiality of these gene products for bacterial replication, to develop screening assays on them, and to conduct large scale screening campaigns on tens of different targets [71,72]. As a result of these efforts, only a small number of lead compounds have been taken to preclinical studies, and the majority of them have never been taken to clinical trials. Many of the screening assays developed within the process have been published and thus they can be adopted for the screening of chemical collections harboring compounds with more antibiotic-like properties. For example, bacterial ribosome biosynthesis can be targeted by screening inhibitors against a bacterial GTPase in an assay using the isolated bacterial enzymes with generally applicable screening methodologies for GTP level detection [102]. As the target proteins are of bacterial origin, their expression and production in quantities required for HTS or MTS is generally not the rate-limiting factor for screening, and generic protocols for detecting the enzymatic activity of question are often readily available.

As mentioned, success on developing new drug candidates by applying target-based approaches has been limited. A major limitation of the target-based approach is that it gives no information on the compound's ability to penetrate bacterial membranes and thus reach the target site. Particularly with gram-negative bacteria, penetration through the bacterial membranes poses a significant challenge with regards to the compounds physicochemical characteristics and is thus critical for the biological activity first hand [70]. One means for taking this into account in target-based screening is by designing whole cell assays for the targets of interest by comparative screening of wild-type and target-depleted strains. By silencing the target of interest by RNAi or other means, the silenced and wild-type strains of the bacterium are expected to have different susceptibilities towards a small molecule modulator of the target. This approach has been successfully used, for example, in the discovery of new and previously known fatty acid biosynthesis (Fab) inhibitors among natural product extracts targeting S. aureus FabF7FabH [103,104]. However, the widely studied Fab as an antibacterial target has revealed one additional challenge in target-based approaches: the essentiality of the target may not be directly interpretable based on its conserved nature, since gram-negative bacteria have later been shown to be resistant to Fab inhibitors [105].

Generally speaking, screening with biochemical assays is prone to false positives due to aggregating behavior of some small molecules, as discussed earlier. In fact beta-lactamases are among the most widely studied enzymatic targets in this respect, and according to the data from Shoichet's laboratory, hit lists from screening campaigns with this target are dominated with promiscuous inhibitors, with an occurrence reaching $97 \%$ of all screening hits [106]. Similarly, Newton et al. [107] reported a screening assay for the synthesis of mycothiol, an essential Mycobacterium tuberculosis, in which 65 of the screening hits from a collection of 2024 compounds were found to be promiscuous, nonspecific inhibitors or to interfere with the photometric readout.

\section{Assaying bacterial virulence factors}

An alternative antibacterial strategy aims at the identification of small molecules inhibiting the activities of virulence factors. One approach, in this respect, is based on the phenotypic assays for virulence factor gene regulation $[108,109]$, while others have addressed the question via the specific virulence mechanisms [110, 111]. One widely conserved virulence factor especially among gram-negative bacteria is the type 3 secretion system (T3SS), a syringe-like protein complex responsible for exosis of bacterial products. Screening assays for the discovery of T3SS inhibitors have been described on several bacteria, generally applying fluorescent of luminescent T3SS substrates detectable from extracel- 
lular space samples $[110,111]$. Another virulence factor targeted by recent screening campaigns is bacterial motility, for which a screening assay utilizing a miniaturized version of the classical soft agar method in combination with viability staining to distinguish growth inhibitors from motility inhibitors has been described [112]. In addition, bacteria-specific exoenzymes have inspired the development of target-based screening assays based on the detection of the cleavage products [113].

\section{Screening for anti-biofilm compounds}

According to an estimate by the U.S. National Institutes of Health, over $65 \%$ of bacterial infections are nowadays recognized to be caused by biofilms [114]. The main challenge posed by biofilms is their increased tolerance to chemotherapy and the host immune responses, which stems from a variety of factors that include the interbacterial communication networks, the production of the extracellular matrix, and the presence of persisters $[114,115]$. Nonbacteriocidal or bacteriostatic approaches for screening anti-biofilm compounds have involved, for instance, targeting signaling pathways [116-118]. Interest in biofilm research has highly increased during the past few years, and efforts towards producing standardized data have expanded involving both assay development and database integration [28, 119-122]. Plants have classically not been considered as sources of potent antibacterial compounds [70]. Yet, although no efficient inhibitors of bacterial growth have been discovered from plants, several plant-derived compounds are known which target bacterial populations by other means. Extracts from garlic and Elmleaf blackberry (Rubus ulnifolius), as well as flavonoids isolated from different plants, have shown anti-biofilm activity [123-127], and in the case of garlic extract, the anti-biofilm activity has also been confirmed in a mouse model [128]. In another study, the anti-biofilm activity of a natural compound originating from garlic was traced to metabolites putatively affecting interbacterial communication and occurred at concentrations that do not affect planktonic bacteria growth [129].

In a screening-compatible manner, a typical procedure to measure biofilm modulating effects is by detecting the biomass of a biofilm grown on the bottom and walls of the wells in a microtiter plate by crystal violet staining. Additionally, metabolic activity of the bacterial biofilms can be determined with viability dyes such as resazurin, and the extracellular matrix can be quantified by a specific dye. Validated screening platforms based on such methods have been described and successfully used for identification of organic small molecules preventing biofilm formation and/or destructing preexisting biofilms (i.e., $[130,131])$. Attempts to miniaturize the crystal violet assay in the 96-well format have been successful and, for instance, a semiautomated protocol for crystal violet staining has been discussed earlier as an example here ( $\odot$ Fig. 4) [28]. To increase throughput, other alternative methods such as an attachment assay described for a Pseudomonas aeruginosa luciferase expressing strain have been developed [131]. In addition, an HCS assay for anti-biofilm studies has been described, based on GFP-expressing bacterial or a combination of fluorescent viability dyes [132,133]. When compared to crystal violet staining, the HCS assay was stated to be significantly more sensitive in detecting surface attachment and other early events in the biofilm life cycle, or simultaneous quantification of non-biofilm forms of the bacteria [132]. Achieving data on biofilm architecture in a high-throughput format may yield screening hits with characteristics different from those identified with conventional methods, but, to the best of our knowledge, re- ports on medium- or large-scale anti-biofilm screens using HCS platforms have not been published thus far.

When it comes to selecting the proper measurement endpoint for anti-biofilm screens, several authors have noticed the importance of combining biomass and viability with matrix measurement methods (i.e., $[119,134]$. Various lines of evidences have shown that compounds that are regarded as effective when they inhibit biomass and/or biofilm viability could, in some cases, promote overproduction (or maintenance) of the biofilm matrix, which thus facilitates biofilm colonization in the long term [135]. Thus, including matrix detection assays could significantly enhance the understanding of the biofilms responses towards anti-biofilm agents and give a better assessment of their genuine clinical relevance. Also, in our opinion, an essential issue that needs to be acknowledged in antibacterial screening is the fact that neither biofilms nor suspended bacteria exist as an isolate lifestyle. Bacteria dynamically switches between them upon changes in host or environmental conditions, and thus the knowledge of the effects that test compounds may have in one or the other state is essential as well.

\section{Conclusions \\ $\nabla$}

The screening of natural products is undoubtedly complicated by their chemical complexity, and even the purified natural compounds are known to be structurally unique and challenging from a bioactivity perspective. However, proper assay validation and implementation can help overcoming these difficulties and lead to the discovery of meaningful natural lead compounds.

Over the last few years, academic screening has become increasingly engaged in chemical screenings, and has come to provide mature and innovative contributions in a way that has reshaped the field, traditionally dominated by the pharmaceutical companies. With the opening of new academic centers worldwide, as well as the launching of large open initiatives (such as EU-OPENSCREEN), a vast array of infrastructures and compound collections have (and will continue to) become available for an even wider community. Thus, it is our goal that some of the strategies discussed here offer methodological guidelines for natural product researchers, as well as encourage others to embrace new efforts in the rewarding path of discovering new drugs from natural sources.

\section{Acknowledgements}

$\nabla$

The authors thank the Academy of Finland for financial support (WoodyFilm project, decision 264064; ArtFilm project, decision 272266) as well as the Drug Discovery and Chemical Biology (DDCB) network of Biocenter Finland. The authors also thank Malena Skogman, Ph.D. and Daniela Karlsson, Ph.D. for kindly contributing some of the drawings and images utilized in - Figs. 1, 3, and 6 .

\section{Conflict of Interest \\ $\nabla$}

The authors declare no conflicts of interest. 


\section{References}

1 Mayr LM, Fuerst $P$. The future of high-throughput screening. J Biomol Screen 2008; 13: 443-448

2 Wölcke J, Ullmann D. Miniaturized HTS technologies - uHTS. Drug Discov Today 2001; 6: 637-646

3 Medina-Franco JL, Giulianotti MA, Welmaker GS, Houghten RA. Shifting from the single to the multitarget paradigm in drug discovery. Drug Discov Today 2013; 18: 495-501

4 Cragg GM, Newman DJ. Natural products: a continuing source of novel drug leads. Biochim Biophys Acta 2013; 1830: 3670-3695

5 Newman DJ, Cragg GM. Natural products as sources of new drugs over the 30 years from 1981 to 2010. J Nat Prod 2012; 75: 311-335

6 Potterat 0 , Hamburger $M$. Natural products in drug discovery - concepts and approaches for tracking bioactivity. Curr Organ Chem 2006; 10: 899-920

7 Macarrón $R$, Hertzberg RP. Design and implementation of highthroughput screening assays. Methods Mol Biol 2009; 565: 1-32

8 Koehn FE, Carter GT. The evolving role of natural products in drug discovery. Nat Rev Drug Discov 2005; 4: 206-220

9 Riihimäki-Lampén LH, Vainio MJ, Vahermo M, Pohjala LL, Heikura JM, Valkonen KH, Virtanen VT, Yli-Kauhaluoma JT, Vuorela PM. The binding of synthetic retinoids to lipocalin beta-lactoglobulins. J Med Chem 2010; 53: 514-518

10 Hasson SA, Inglese J. Innovation in academic chemical screening: filling the gaps in chemical biology. Curr Opin Chem Biol 2013; 17: 329-338

11 Inglese J, Johnson RL, Simeonov A, Xia M, Zheng W, Austin CP, Auld DS. High-throughput screening assays for the identification of chemical probes. Nat Chem Biol 2007; 3: 466-479

12 Coma I, Herranz J, Martin J. Statistics and decision making in highthroughput screening. Methods Mol Biol 2009; 565: 69-106

13 Macarron R, Banks MN, Bojanic D, Burns DJ, Cirovic DA, Garyantes T, Green DV, Hertzberg RP, Janzen WP, Paslay JW, Schopfer U, Sittampalam GS. Impact of high-throughput screening in biomedical research. Nat Rev Drug Discov 2011; 10: 188-195

14 Larsen MJ, Larsen SD, Fribley A, Grembecka J, Homan K, Mapp A, Haak A, Nikolovska-Coleska Z, Stuckey JA, Sun D, Sherman DH. The role of HTS in drug discovery at the University of Michigan. Comb Chem High Throughput Screen 2014; 17: 210-230

15 Brenk R, Schipani A, James D, Krasowski A, Gilbert IH, Frearson J, Wyatt $P G$. Lessons learnt from assembling screening libraries for drug discovery for neglected diseases. ChemMedChem 2008; 3: 435-444

16 Wen Q Goldenson B, Silver SJ, Schenone M, Dancik V, Huang Z, Wang LZ, Lewis TA, An WF, Li X, Bray MA, Thiollier C, Diebold L, Gilles L, Vokes MS, Moore CB, Bliss-Moreau M, Verplank L, Tolliday NJ, Mishra R, Vemula S, Shi J, Wei L, Kapur R, Lopez CK, Gerby B, Ballerini P, Pflumio F, Gilliland DG, Goldberg L, Birger Y, Izraeli S, Gamis AS, Smith FO, Woods WG, Taub J, Scherer CA, Bradner JE, Goh BC, Mercher T, Carpenter AE, Gould RJ, Clemons PA, Carr SA, Root DE, Schreiber SL, Stern AM, Crispino JD. Identification of regulators of polyploidization presents therapeutic targets for treatment of AMKL. Cell 2012; 150: 575-589

17 Allan C, Burel JM, Moore J, Blackburn C, Linkert M, Loynton S, Macdonald $D$, Moore WJ, Neves C, Patterson A, Porter M, Tarkowska A, Loranger B, Avondo J, Lagerstedt I, Lianas L, Leo S, Hands K, Hay RT, Patwardhan A, Best C, Kleywegt GJ, Zanetti G, Swedlow JR. OMERO: flexible, modeldriven data management for experimental biology. Nat Methods 2012; 9: 245-253

18 Gosai SJ, Kwak JH, Luke CJ, Long OS, King DE, Kovatch KJ, Johnston PA, Shun TY, Lazo JS, Perlmutter DH, Silverman GA, Pak SC. Automated high-content live animal drug screening using $C$. elegans expressing the aggregation prone serpin $\alpha 1$-antitrypsin Z. PLoS One 2010; 5: e15460

19 Coma I, Clark L, Diez E, Harper G, Herranz J, Hofmann G, Lennon M, Richmond $N$, Valmaseda M, Macarron R. Process validation and screen reproducibility in high-throughput screening. J Biomol Screen 2009; 14: 66-76

20 Zhang JH, Chung TD, Oldenburg KR. A simple statistical parameter for use in evaluation and validation of high throughput screening assays. J Biomol Screen 1999; 4: 67-73

21 Bollini S, Herbst JJ, Gaughan GT, Verdoorn TA, Ditta J, Dubowchik GM, Vinitsky A. High-throughput fluorescence polarization method for identification of FKBP12 ligands. J Biomol Screen 2002; 7: 526-530

22 Iversen PW, Eastwood BJ, Sittampalam GS, Cox KL. A comparison of assay performance measures in screening assays: signal window, $Z^{\prime}$ factor, and assay variability ratio. J Biomol Screen 2006; 11: 247-252
23 Fox S, Farr-Jones S, Sopchak L, Boggs A, Nicely HW, Khoury R, Biros M. High-throughput screening: update on practices and success. J Biomol Screen 2006; 11: 864-869

24 Soikkeli A, Sempio C, Kaukonen AM, Urtti A, Hirvonen J, Yliperttula M. Feasibility evaluation of 3 automated cellular drug screening assays on a robotic workstation. J Biomol Screen 2010; 15: 30-41

25 Hurst WJ, Mortimer JW. Laboratory robotics, a guide to planning, programming and applications. Birmingham, England: VCH Publishers, Inc.; 1987

26 Taylor PB, Ashman S, Baddeley SM, Bartram SL, Battle CD, Bond BC, Clements YM, Gaul NJ, McAllister WE, Mostacero JA, Ramon F, Wilson JM, Hertzberg RP, Pope AJ, Macarron R. A standard operating procedure for assessing liquid handler performance in high-throughput screening. J Biomol Screen 2002; 7: 554-569

27 Berg M, Undisz K, Thiericke R, Zimmermann P, Moore T, Posten C. Evaluation of liquid handling conditions in microplates. J Biomol Screen 2001; 6: 47-56

28 Sandberg M, Määttänen A, Peltonen J, Vuorela PM, Fallarero A. Automating a 96-well microtitre plate model for Staphylococcus aureus biofilms: an approach to screening of natural antimicrobial compounds. Int J Antimicrob Agents 2008; 32: 233-240

29 Feng BY, Simeonov A, Jadhav A, Babaoglu K, Inglese J, Shoichet BK, Austin $C P$. A high-throughput screen for aggregation-based inhibition in a large compound library. J Med Chem 2007; 50: 2385-2390

30 McGovern SL, Caselli E, Grigorieff N, Shoichet BK. A common mechanism underlying promiscuous inhibitors from virtual and high-throughput screening. J Med Chem 2002; 45: 1712-1722

31 McGovern SL, Shoichet BK. Kinase inhibitors: not just for kinases anymore. J Med Chem 2003; 46: 1478-1483

32 Coan KE, Maltby DA, Burlingame AL, Shoichet BK. Promiscuous aggregate-based inhibitors promote enzyme unfolding. J Med Chem 2009; 52: 2067-2075

33 Coan KE, Shoichet BK. Stoichiometry and physical chemistry of promiscuous aggregate-based inhibitors. J Am Chem Soc 2008; 130: 96069612

34 Feng $B Y$, Shoichet $B K$. A detergent-based assay for the detection of promiscuous inhibitors. Nat Protoc 2006; 1: 550-553

35 Han R. Highlight on the studies of anticancer drugs derived from plants in China. Stem Cells 1994; 12: 53-63

36 Han $R$. Recent progress in the study of anticancer drugs originating from plants and traditional medicines in China. Chin Med Sci J 1994; 9: 61-69

37 Clements RT, Cordeiro B, Feng J, Bianchi C, Sellke FW. Rottlerin increases cardiac contractile performance and coronary perfusion through BKCa ++ channel activation after cold cardioplegic arrest in isolated hearts. Circulation 2011: 124: S55-S61

38 Sassano MF, Doak AK, Roth BL, Shoichet BK. Colloidal aggregation causes inhibition of G protein-coupled receptors. J Med Chem 2013; 56: 2406-2414

39 Giannetti AM, Koch BD, Browner MF. Surface plasmon resonance based assay for the detection and characterization of promiscuous inhibitors. J Med Chem 2008; 51: 574-580

40 Pohjala L, Tammela P. Aggregating behavior of phenolic compounds - a source of false bioassay results? Molecules 2012; 17: 10774-10790

41 Ryan AJ, Gray NM, Lowe PN, Chung CW. Effect of detergent on "promiscuous" inhibitors. J Med Chem 2003; 46: 3448-3451

42 Pohjala LL, Sairio NK, Vuorela PM. Interference by bovine serum albumin in PED6 based phospholipase A2 screening assays. Pharmazie 2012; 67: 954-955

43 Chan LL, Lidstone EA, Finch KE, Heeres JT, Hergenrother PJ, Cunningham $B T$. A method for identifying small-molecule aggregators using photonic crystal biosensor microplates. JALA Charlottesv Va 2009; 14: 348-359

44 Seidler J, McGovern SL, Doman TN, Shoichet BK. Identification and prediction of promiscuous aggregating inhibitors among known drugs. J Med Chem 2003; 46: 4477-4486

$45 \mathrm{Gao} \mathrm{H}$, Shanmugasundaram V, Lee P. Estimation of aqueous solubility of organic compounds with QSPR approach. Pharm Res 2002; 19: 497503

46 Larsson J, Gottfries J, Muresan S, Backlund A. ChemGPS-NP: tuned for navigation in biologically relevant chemical space. J Nat Prod 2007; 70: 789-794

47 Rosén J, Lövgren A, Kogej T, Muresan S, Gottfries J, Backlund A. ChemGPS-NP(Web): chemical space navigation online. J Comput Aided Mol Des 2009; 23: 253-259 
48 Schneider R, Gohla A, Simard JR, Yadav DB, Fang Z, van Otterlo WA, Rauh $D$. Overcoming compound fluorescence in the FLiK screening assay with red-shifted fluorophores. J Am Chem Soc 2013; 135: 8400-8408

49 Kraus B, Ziegler $M$, Wolff $H$. Linear fluorescence unmixing in cell biological research. In: Méndez-Vilas A, Díaz J, editors. Modern research and educational topics in microscopy. Volume 2. Badajoz, Spain: Formatex; 2007: 863-872 (Available online: http://www.formatex.org/microscopy3/)

50 Shapiro AB, Walkup GK, Keating TA. Correction for interference by test samples in high-throughput assays. J Biomol Screen 2009; 14: 10081016

51 Jadhav A, Ferreira RS, Klumpp C, Mott BT, Austin CP, Inglese J, Thomas CJ, Maloney DJ, Shoichet BK, Simeonov A. Quantitative analyses of aggregation, autofluorescence, and reactivity artifacts in a screen for inhibitors of a thiol protease. J Med Chem 2010; 53: 37-51

52 Narwal M, Fallarero A, Vuorela P, Lehtiö L. Homogeneous screening assay for human tankyrase. J Biomol Screen 2012; 17: 593-604

53 RyukJA, Zheng MS, Lee MY, Seo CS, Li Y, Lee SH, Moon DC, Lee HW, Lee JH, Park JY, Son JK, Ko BS. Discrimination of Phellodendron amurense and $P$. chinense based on DNA analysis and the simultaneous analysis of alkaloids. Arch Pharm Res 2012; 35: 1045-1054

54 Grant SK, Sklar JG, Cummings RT. Development of novel assays for proteolytic enzymes using rhodamine-based fluorogenic substrates. J Biomol Screen 2002; 7: 531-540

55 Turek-Etienne TC, Lei M, Terracciano JS, Langsdorf EF, Bryant RW, Hart $R F$, Horan $A C$. Use of red-shifted dyes in a fluorescence polarization AKT kinase assay for detection of biological activity in natural product extracts. J Biomol Screen 2004; 9: 52-61

56 Shiau AK, Massari ME, Ozbal CC. Back to basics: label-free technologies for small molecule screening. Comb Chem High Throughput Screen 2008; 11: 231-237

57 Fang Y. Label-free drug discovery. Front Pharmacol 2014; 5: 52

58 George S, Bhalerao SV, Lidstone EA, Ahmad IS, Abbasi A, Cunningham BT, Watkin KL. Cytotoxicity screening of Bangladeshi medicinal plant extracts on pancreatic cancer cells. BMC Complement Altern Med 2010; 10: 52

59 Chan LL, Gosangari SL, Watkin KL, Cunningham BT. Label-free imaging of cancer cells using photonic crystal biosensors and application to cytotoxicity screening of a natural compound library. Sens Actuators B Chem 2008; 132: 418-425

60 Chan LL, George S, Ahmad I, Gosangari SL, Abbasi A, Cunningham BT, Watkin KL. Cytotoxicity effects of Amoora rohituka and chittagonga on breast and pancreatic cancer cells. Evid Based Complement Alternat Med 2011; 2011: 860605

61 Kling B, Bücherl D, Palatzky P, Matysik FM, Decker M, Wegener J, Heilmann J. Flavonoids, flavonoid metabolites, and phenolic acids inhibit oxidative stress in the neuronal cell line HT-22 monitored by ECIS and MTT assay: a comparative study. J Nat Prod 2014; 77: 446-454

62 Bruggisser R, von Daeniken K, Jundt G, Schaffner W, Tullberg-Reinert $H$. Interference of plant extracts, phytoestrogens and antioxidants with the MTT tetrazolium assay. Planta Med 2002; 68: 445-448

63 Soriano FX, Galbete JL, Forloni G. Effect of beta-amyloid on endothelial cells: lack of direct toxicity, enhancement of MTT-induced cell death and intracellular accumulation. Neurochem Int 2003; 43: 251-261

64 Shoemaker M, Cohen I, Campbell M. Reduction of MTT by aqueous herbal extracts in the absence of cells. J Ethnopharmacol 2004; 93: 381-384

65 Minor LK. Label-free cell-based functional assays. Comb Chem High Throughput Screen 2008; 11: 573-580

66 Xi B, Yu N, Wang X, Xu X, Abassi YA. The application of cell-based labelfree technology in drug discovery. Biotechnol J 2008; 3: 484-495

67 Rodvold KA, McConeghy KW. Methicillin-resistant Staphylococcus aureus therapy: past, present, and future. Clin Infect Dis 2014; 58 Suppl. 1: S20-S27

68 Noskin GA. Prevention of infection in immunocompromised hosts. Cancer Treat Res 1998; 96: 223-246

69 Kester JC, Fortune SM. Persisters and beyond: mechanisms of phenotypic drug resistance and drug tolerance in bacteria. Crit Rev Biochem Mol Biol 2014; 49: 91-101

70 Lewis K. Platforms for antibiotic discovery. Nat Rev Drug Discov 2013; 12: $371-387$

71 Payne DJ, Gwynn MN, Holmes DJ, Pompliano DL. Drugs for bad bugs: confronting the challenges of antibacterial discovery. Nat Rev Drug Discov 2007; 6: 29-40
72 Chopra I. The 2012 Garrod lecture: discovery of antibacterial drugs in the 21st century. J Antimicrob Chemother 2013; 68: 496-505

73 Silver $L L$. Challenges of antibacterial discovery. Clin Microbiol Rev 2011; 24: 71-109

74 Powers JH. Antimicrobial drug development-the past, the present, and the future. Clin Microbiol Infect 2004; 10 Suppl. 4: 23-31

75 Niño J, Mosquera OM, Correa YM. Antibacterial and antifungal activities of crude plant extracts from Colombian biodiversity. Rev Biol Trop 2012; 60: 1535-1542

76 Luciano-Montalvo C, Boulogne I, Gavillán-Suárez J. A screening for antimicrobial activities of Caribbean herbal remedies. BMC Complement Altern Med 2013; 13: 126

77 Gertsch J. Botanical drugs, synergy, and network pharmacology: forth and back to intelligent mixtures. Planta Med 2011; 77: 1086-1098

78 Sánchez-Hidalgo M, Pascual J, de la Cruz M, Martín J, Kath GS, Sigmund JM, Masurekar P, Vicente F, Genilloud O, Bills GF. Prescreening bacterial colonies for bioactive molecules with Janus plates, a SBS standard double-faced microbial culturing system. Antonie Van Leeuwenhoek 2012; 102: 361-374

79 Berke I, Tierno PM. Comparison of efficacy and cost-effectiveness of BIOMIC VIDEO and Vitek antimicrobial susceptibility test systems for use in the clinical microbiology laboratory. J Clin Microbiol 1996; 34: 1980-1984

80 Jorgensen JH, Ferraro MJ. Antimicrobial susceptibility testing: a review of general principles and contemporary practices. Clin Infect Dis 2009; 49: $1749-1755$

81 Ymele-Leki P, Cao S, Sharp J, Lambert KG, McAdam AJ, Husson RN, Tamayo G, Clardy J, Watnick PI. A high-throughput screen identifies a new natural product with broad-spectrum antibacterial activity. PLoS One 2012; 7: e31307

82 Xu M, Davis RA, Feng Y, Sykes ML, Shelper T, Avery VM, Camp D, Quinn RJ. Ianthelliformisamines $\mathrm{A}-\mathrm{C}$, antibacterial bromotyrosine-derived metabolites from the marine sponge Suberea ianthelliformis. J Nat Prod 2012; 75: 1001-1005

83 Scanlon TC, Dostal SM, Griswold KE. A high-throughput screen for antibiotic drug discovery. Biotechnol Bioeng 2014; 111: 232-243

84 Nybond S, Karp M, Tammela P. Antimicrobial assay optimization and validation for HTS in 384-well format using a bioluminescent $E$. coli K-12 strain. Eur J Pharm Sci 2013; 49: 782-789

85 Osterman IA, Prokhorova IV, Sysoev VO, Boykova YV, Efremenkova OV Svetlov MS, Kolb VA, Bogdanov AA, Sergiev PV, Dontsova OA. Attenuation-based dual-fluorescent-protein reporter for screening translation inhibitors. Antimicrob Agents Chemother 2012; 56: 1774-1783

86 Auld DS, Thorne N, Nguyen DT, Inglese J. A specific mechanism for nonspecific activation in reporter-gene assays. ACS Chem Biol 2008; 3 : 463-470

87 Auld DS, Southall NT, Jadhav A, Johnson RL, Diller DJ, Simeonov A, Austin $C P$, Inglese J. Characterization of chemical libraries for luciferase inhibitory activity. J Med Chem 2008; 51: 2372-2386

88 Bakhtiarova A, Taslimi P, Elliman SJ, Kosinski PA, Hubbard B, Kavana M, Kemp DM. Resveratrol inhibits firefly luciferase. Biochem Biophys Res Commun 2006: 351: 481-484

89 Alvesalo J, Vuorela H, Tammela P, Leinonen M, Saikku P, Vuorela P. Inhibitory effect of dietary phenolic compounds on Chlamydia pneumoniae in cell cultures. Biochem Pharmacol 2006; 71: 735-741

90 Salin O, Alakurtti S, Pohjala L, Siiskonen A, Maass V, Maass M, Yli-Kauhaluoma J, Vuorela P. Inhibitory effect of the natural product betulin and its derivatives against the intracellular bacterium Chlamydia pneumoniae. Biochem Pharmacol 2010; 80: 1141-1151

91 Christophe T, Jackson M, Jeon HK, Fenistein D, Contreras-Dominguez M, Kim J, Genovesio A, Carralot JP, Ewann F, Kim EH, Lee SY, Kang S, Seo MJ, Park EJ, Skovierová H, Pham H, Riccardi G, Nam JY, Marsollier L, Kempf M, Joly-Guillou ML, Oh T, Shin WK, No Z, Nehrbass U, Brosch R, Cole ST, Bro$\operatorname{din} P$. High content screening identifies decaprenyl-phosphoribose $2^{\prime}$ epimerase as a target for intracellular antimycobacterial inhibitors. PLoS Pathog 2009; 5: e1000645

92 Peach KC, Bray WM, Winslow D, Linington PF, Linington RG. Mechanism of action-based classification of antibiotics using high-content bacterial image analysis. Mol Biosyst 2013; 9: 1837-1848

93 O'Rourke EJ, Conery AL, Moy TI. Whole-animal high-throughput screens: the C. elegans model. Methods Mol Biol 2009; 486: 57-75

94 Moy TI, Conery AL, Larkins-Ford J, Wu G, Mazitschek R, Casadei G, Lewis $K$, Carpenter AE, Ausubel FM. High-throughput screen for novel antimicrobials using a whole animal infection model. ACS Chem Biol 2009; 4: 527-533 
95 Durai S, Vigneshwari L, Balamurugan K. Caenorhabditis elegans-based in vivo screening of bioactives from marine sponge-associated bacteria against Vibrio alginolyticus. J Appl Microbiol 2013; 115: 13291342

96 Cheng B, Cao S, Vasquez V, Annamalai T, Tamayo-Castillo G, Clardy J, Tse-Dinh YC. Identification of anziaic acid, a lichen depside from Hypotrachyna sp., as a new topoisomerase poison inhibitor. PLoS One 2013; 8: e60770

$97 \mathrm{Kim}$ S, Lee SW, Choi EC, Choi SY. Aminoacyl-tRNA synthetases and their inhibitors as a novel family of antibiotics. Appl Microbiol Biotechnol 2003; 61: 278-288

98 Chan DC, Anderson AC. Towards species-specific antifolates. Curr Med Chem 2006; 13: 377-398

99 Lewis K, Ausubel FM. Prospects for plant-derived antibacterials. Nat Biotechnol 2006; 24: 1504-1507

100 Stavri M, Piddock LJ, Gibbons S. Bacterial efflux pump inhibitors from natural sources. J Antimicrob Chemother 2007; 59: 1247-1260

101 Zervosen A, Sauvage E, Frère JM, Charlier P, Luxen A. Development of new drugs for an old target: the penicillin binding proteins. Molecules 2012; 17: 12478-12505

102 Bharat A, Blanchard JE, Brown ED. A high-throughput screen of the GTPase activity of Escherichia coli EngA to find an inhibitor of bacterial ribosome biogenesis. J Biomol Screen 2013; 18: 830-836

103 Ondeyka JG, Zink DL, Young K, Painter R, Kodali S, Galgoci A, Collado J, Tormo JR, Basilio A, Vicente F, Wang J, Singh SB. Discovery of bacterial fatty acid synthase inhibitors from a Phoma species as antimicrobial agents using a new antisense-based strategy. J Nat Prod 2006; 69: 377-380

104 Young K, Jayasuriya H, Ondeyka JG, Herath K, Zhang C, Kodali S, Galgoci A, Painter R, Brown-Driver V, Yamamoto R, Silver LL, Zheng Y, Ventura JI, Sigmund J, Ha S, Basilio A, Vicente F, Tormo JR, Pelaez F, Youngman P, Cully D, Barrett JF, Schmatz D, Singh SB, Wang J. Discovery of FabH/FabF inhibitors from natural products. Antimicrob Agents Chemother 2006; 50: 519-526

105 Brötz-Oesterhelt H, Sass P. Postgenomic strategies in antibacterial drug discovery. Future Microbiol 2010; 5: 1553-1579

106 Babaoglu K, Simeonov A, Irwin JJ, Nelson ME, Feng B, Thomas CJ, Cancian L, Costi MP, Maltby DA, Jadhav A, Inglese J, Austin CP, Shoichet BK. Comprehensive mechanistic analysis of hits from high-throughput and docking screens against beta-lactamase. J Med Chem 2008; 51 : 2502-2511

107 Newton GL, Ta P, Sareen D, Fahey RC. A coupled spectrophotometric assay for l-cysteine:1-D-myo-inosityl 2-amino-2-deoxy-alpha-D-glucopyranoside ligase and its application for inhibitor screening. Anal Biochem 2006; 353: 167-173

108 Hurt JK, McQuade TJ, Emanuele A, Larsen MJ, Garcia GA. High-throughput screening of the virulence regulator VirF: a novel antibacterial target for shigellosis. J Biomol Screen 2010; 15: 379-387

109 Sun H, Xu Y, Sitkiewicz I, Ma Y, Wang X, Yestrepsky BD, Huang Y, Lapadatescu MC, Larsen MJ, Larsen SD, Musser JM, Ginsburg D. Inhibitor of streptokinase gene expression improves survival after group A streptococcus infection in mice. Proc Natl Acad Sci U S A 2012; 109: 3469_ 3474

110 Pan N, Lee C, Goguen J. High throughput screening for small-molecule inhibitors of type III secretion in Yersinia pestis. Adv Exp Med Biol 2007; 603: 367-375

111 Yamazaki A, Li J, Zeng Q Khokhani D, Hutchins WC, Yost AC, Biddle E, Toone EJ, Chen X, Yang $C H$. Derivatives of plant phenolic compound affect the type III secretion system of Pseudomonas aeruginosa via a GacS-GacA two-component signal transduction system. Antimicrob Agents Chemother 2012; 56: 36-43

112 Rasmussen L, White EL, Pathak A, Ayala JC, Wang H, Wu JH, Benitez JA, Silva AJ. A high-throughput screening assay for inhibitors of bacterial motility identifies a novel inhibitor of the Na+-driven flagellar motor and virulence gene expression in Vibrio cholerae. Antimicrob Agents Chemother 2011: 55: 4134-4143

113 Garner AL, Fullagar JL, Day JA, Cohen SM, Janda KD. Development of a high-throughput screen and its use in the discovery of Streptococcus pneumoniae immunoglobulin A1 protease inhibitors. J Am Chem Soc 2013; 135: 10014-10017

114 Bjarnsholt T, Ciofu O, Molin S, Givskov M, Høiby N. Applying insights from biofilm biology to drug development - can a new approach be developed? Nat Rev Drug Discov 2013; 12: 791-808
115 Van Acker H, Van Dijck P, Coenye T. Molecular mechanisms of antimicrobial tolerance and resistance in bacterial and fungal biofilms. Trends Microbiol 2014; 22: 326-333

116 Antoniani D, Bocci P, Maciag A, Raffaelli N, Landini P. Monitoring of diguanylate cyclase activity and of cyclic-di-GMP biosynthesis by whole-cell assays suitable for high-throughput screening of biofilm inhibitors. Appl Microbiol Biotechnol 2010; 85: 1095-1104

117 Brackman G, Cos P, Maes L, Nelis HJ, Coenye T. Quorum sensing inhibitors increase the susceptibility of bacterial biofilms to antibiotics in vitro and in vivo. Antimicrob Agents Chemother 2011; 55: 2655-2661

118 Brackman $G$, Celen $S$, Hillaert $U$, Van Calenbergh $S$, Cos $P$, Maes L, Nelis HJ, Coenye T. Structure-activity relationship of cinnamaldehyde analogs as inhibitors of AI-2 based quorum sensing and their effect on virulence of Vibrio spp. PLoS One 2011; 6: e16084

119 Peeters E, Nelis HJ, Coenye T. Comparison of multiple methods for quantification of microbial biofilms grown in microtiter plates. J Microbiol Methods 2008; 72: 157-165

120 Kwasny SM, Opperman TJ. Static biofilm cultures of Gram-positive pathogens grown in a microtiter format used for anti-biofilm drug discovery. Curr Protoc Pharmacol 2010; Chapter 13: Unit 13A.18

121 Lourenço A, Coenye T, Goeres DM, Donelli G, Azevedo AS, Ceri H, Coelho FL, Flemming HC, Juhna T, Lopes SP, Oliveira R, Oliver A, Shirtliff ME, Sousa AM, Stoodley P, Pereira MO, Azevedo NF. Minimum information about a biofilm experiment (MIABiE): standards for reporting experiments and data on sessile microbial communities living at interfaces. Pathog Dis 2014: 70: 250-256

122 Parker AE, Walker DK, Goeres DM, Donelli G, Azevedo AS, Ceri H, Coelho FL, Flemming HC, Juhna T, Lopes SP, Oliveira R, Oliver A, Shirtliff ME, Sousa AM, Stoodley P, Pereira MO, Azevedo NF. Ruggedness and reproducibility of the MBEC biofilm disinfectant efficacy test. J Microbiol Methods 2014; 102: 55-64

123 Quave CL, Estévez-Carmona M, Compadre CM, Hobby G, Hendrickson $H$, Beenken KE, Smeltzer MS. Ellagic acid derivatives from Rubus ulmifolius inhibit Staphylococcus aureus biofilm formation and improve response to antibiotics. PLoS One 2012; 7: e28737

124 Lee JH, Regmi SC, Kim JA, Cho MH, Yun H, Lee CS, Lee J. Apple flavonoid phloretin inhibits Escherichia coli 0157:H7 biofilm formation and ameliorates colon inflammation in rats. Infect Immun 2011; 79; 4819-4827

125 Vikram A, Jayaprakasha GK, Jesudhasan PR, Pillai SD, Patil BS. Suppression of bacterial cell-cell signalling, biofilmformation and type III secretion system by citrus flavonoids. J Appl Microbiol 2010; 109: 515 527

126 Manner S, Skogman M, Goeres D, Vuorela P, Fallarero A. Systematic exploration of natural and synthetic flavonoids for the inhibition of Staphylococcus aureus biofilms. Int J Mol Sci 2013; 14: 19434-19451

127 Bräunlich M, Økstad OA, Slimestad R, Wangensteen H, Malterud KE, Barsett $H$. Effects of Aronia melanocarpa constituents on biofilm formation of Escherichia coli and Bacillus cereus. Molecules 2013; 18: 14989-14999

128 Bjarnsholt T, Jensen P, Rasmussen TB, Christophersen L, Calum H, Hentzer M, Hougen HP, Rygaard J, Moser C, Eberl L, Høiby N, Givskov M. Garlic blocks quorum sensing and promotes rapid clearing of pulmonary Pseudomonas aeruginosa infections. Microbiology 2005; 151: 3873 3880

129 Jakobsen TH, van Gennip M, Phipps RK, Shanmugham MS, Christensen LD, Alhede M, Skindersoe ME, Rasmussen TB, Friedrich $K$, Uthe F, Jensen PØ, Moser C, Nielsen KF, Eberl L, Larsen TO, Tanner D, Høiby N, Bjarnsholt T, Givskov M. Ajoene, a sulfur-rich molecule from garlic, inhibits genes controlled by quorum sensing. Antimicrob Agents Chemother 2012; 56: 2314-2325

130 Sandberg ME, Schellmann D, Brunhofer G, Erker T, Busygin I, Leino $R$ Vuorela PM, Fallarero A. Pros and cons of using resazurin staining for quantification of viable Staphylococcus aureus biofilms in a screening assay. J Microbiol Methods 2009; 78: 104-106

131 Junker LM, Clardy J. High-throughput screens for small-molecule inhibitors of Pseudomonas aeruginosa biofilm development. Antimicrob Agents Chemother 2007; 51: 3582-3590

132 Peng F, Hoek EM, Damoiseaux R. High-content screening for biofilm assays. J Biomol Screen 2010; 15: 748-754

133 Peach KC, Bray WM, Shikuma NJ, Gassner NC, Lokey RS, Yildiz FH, Linington $R G$. An image-based 384-well high-throughput screening method for the discovery of biofilm inhibitors in Vibrio cholerae. Mol Biosyst 2011; 7: 1176-1184 
134 Toté K, Vanden Berghe D, Deschacht M, de Wit K, Maes L, Cos P. Inhibitory efficacy of various antibiotics on matrix and viable mass of Staphylococcus aureus and Pseudomonas aeruginosa biofilms. Int J Antimicrob Agents 2009; 33: 525-531

135 Skogman ME, Vuorela PM, Fallarero A. Combining biofilm matrix measurements with biomass and viability assays in susceptibility assessments of antimicrobials against Staphylococcus aureus biofilms. J Antibiot (Tokyo) 2012; 65: 453-459

136 Fedarovich A, Djordjevic KA, Swanson SM, Peterson YK, Nicholas RA, Davies $C$. High-throughput screening for novel inhibitors of Neisseria gonorrhoeae penicillin-binding protein 2. PLoS One 2012; 7: e44918

137 Llano-Sotelo B, Hickerson RP, Lancaster L, Noller HF, Mankin AS. Fluorescently labeled ribosomes as a tool for analyzing antibiotic binding. RNA 2009; 15: 1597-1604

138 Watkins D, Norris FA, Kumar S, Arya DP. A fluorescence-based screen for ribosome binding antibiotics. Anal Biochem 2013; 434: 300-307
139 Xie Y, Dix AV, Tor Y. FRET enabled real time detection of RNA-small molecule binding. J Am Chem Soc 2009; 131: 17605-17614

140 Kaul M, Barbieri CM, Pilch DS. Fluorescence-based approach for detecting and characterizing antibiotic-induced conformational changes in ribosomal RNA: comparing aminoglycoside binding to prokaryotic and eukaryotic ribosomal RNA sequences. J Am Chem Soc 2004; 126: 3447-3453

141 Kumar A, Zhang M, Zhu L, Liao RP, Mutai C, Hafsat S, Sherman DR, Wang $M W$. High-throughput screening and sensitized bacteria identify an M. tuberculosis dihydrofolate reductase inhibitor with whole cell activity. PLoS One 2012; 7: e39961

142 Hevener KE, Yun MK, Qi J, Kerr ID, Babaoglu K, Hurdle JG, Balakrishna K, White $S W$, Lee RE. Structural studies of pterin-based inhibitors of dihydropteroate synthase. J Med Chem 2010; 53: 166-177 